Portland State University

PDXScholar

$5-1-1970$

\title{
Studies on the distribution and habitat of Demodex folliculorum
}

Michael James Gimbol

Portland State University

Follow this and additional works at: https://pdxscholar.library.pdx.edu/open_access_etds Let us know how access to this document benefits you.

\section{Recommended Citation}

Gimbol, Michael James, "Studies on the distribution and habitat of Demodex folliculorum" (1970). Dissertations and Theses. Paper 58.

https://doi.org/10.15760/etd.58

This Thesis is brought to you for free and open access. It has been accepted for inclusion in Dissertations and Theses by an authorized administrator of PDXScholar. Please contact us if we can make this document more accessible: pdxscholar@pdx.edu. 
AN ABSTRACT OF THE THESIS OF Micheel Janes Gimool for the Master of Science in Biology presented May 22, 1970.

Title: Studies on the Distribution and Habitat of Demodex fo11iculorum.

APFROVED BY MEMBERS OF THE THESIS COMITTEE:

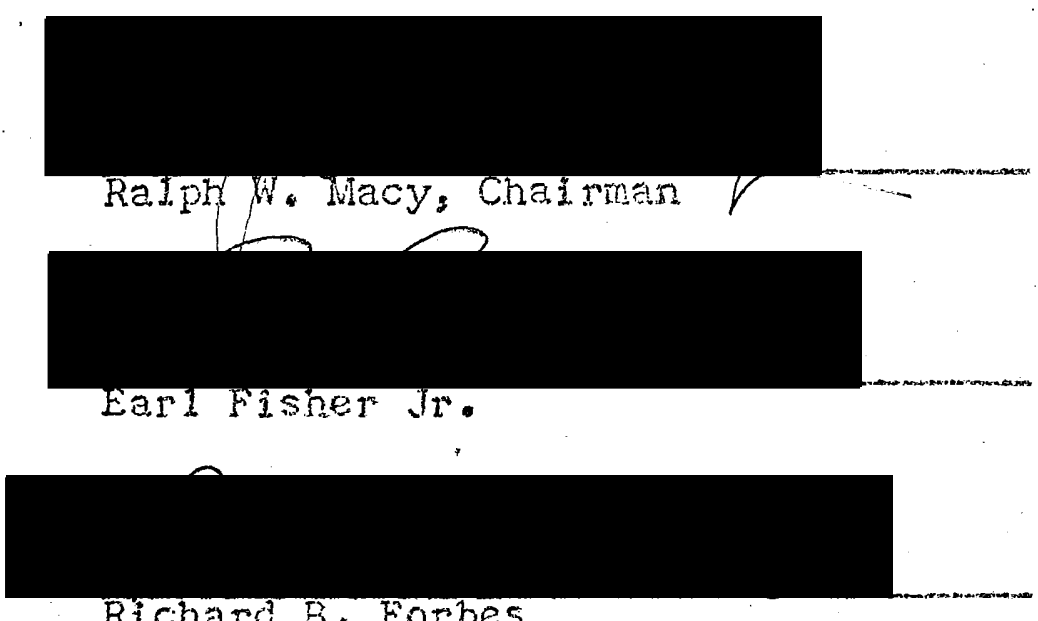

Richard B* Forbes

The present study was undertaken to determine the inciderce of infestation with Demodex fol1iculorum, a skin mite parasitizing man, and to investigate tinose factors which influence its occurrence. These factors wene the personal hygiene, sex, age ard skin concition of the human host. A detailed view of the habjtat of this parasjte is also inciuded so that the controversy surrounding its role as a possible pathogen or vector of disease could be explored in 1 ight of the current knowledge.

A number of sites ot infestation were sampled by a 
number of different techniques. The primary sample site was the nasal area of the face which was examined by slit lamp magnification after chemical application to partial1y expose the mites. A secondary site involved the eyelash follicles from which the lashes were epilated and examined for mites under the microscope.

The 4.1 subjects examined in the nasal area were tabulated by age, sex and skin condition and the incidence of infestation was computed for each of five age groups. There was a definite increase in incidence of Demodex with the advancing age of the host and the normal and oily skin conditions appeared to be much more involved than the dry skin condition. A similar increase in incidence with advancing age was apparent in the 1.43 subjects whose eyelashes were examined. The results from both areas exhibited a statistical correlation between the age and skin condition of the human host and the presence of mites.

The explanation of the increase in incidence with the advancing age of the human host is based on the development and secretory rate of the sebaceous glands of the human host. Past studies have shown that Demodex lives in and around the sebaceous glands of the skin and feeds on sebaceous material and cellular debris. The face appears to be the haibitat of opinmum occurrence which corresponds to the distribution of sebaceous follicles and glands whose size and rate of secretion are greater than thuse over most 
of the body. The role of Demodex in the formation of ingrown hairs on the neck is discussed as a possible, new clinical entity.

The influence of the host's personal hygienic habits on demodectic infestation remains rather obscure. Although the accumulation of sebaceous material would tend to favor the maintenance of mites, the reservoirs of the sebaceous follicles of the face in which the mites are found are not effected by normal soap and water cleansing. Inhabitation of the eyelash follicles may be enhanced by ineffective cleansing, but more study is needed to determine the validity of this contention.

The finding of selective sites of infestation on the human host led to speculation on the possibility of physiol. ogical races of Demodex.

Although it is difficult to determine the validity of reports by earlier workers, there appears to be a decreasing trend in the incidence of Demodex fol1iculorum since its discovery over a century ago. 


\title{
STUDIES ON THE DISTRIBUTION AND HABITAT OF DEMODEX FOLLICULORUM
}

\author{
by \\ MICHAEL JAMES GIMBOL
}

A thesis submitted in partial fulfillment of the requirements for the degree of.

\author{
MASTER OF SCIENCE \\ in \\ BIOLOGY
}

\author{
Portland State University
1970
}


TO THE OFFICE OF GRADUATE STUDIES:

The members of the Committee approve the thesis of Michael James Gimbol presented May 22, 1970.

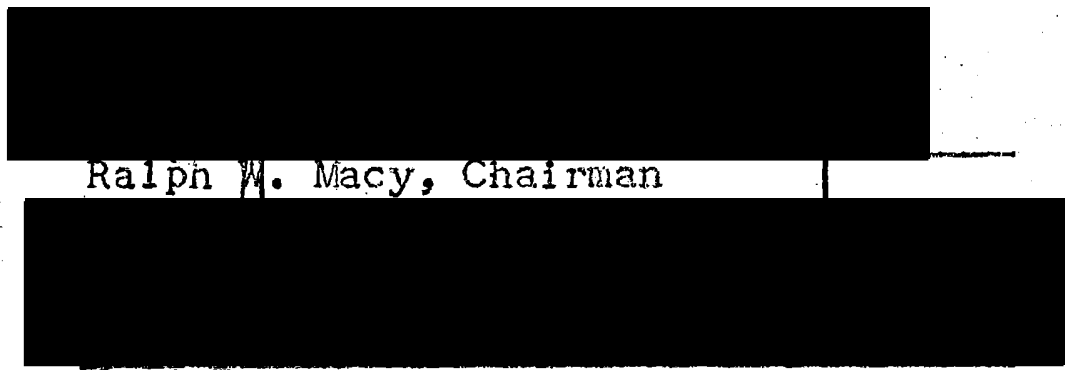

$$
\text { Eard Fisher Jr. }
$$

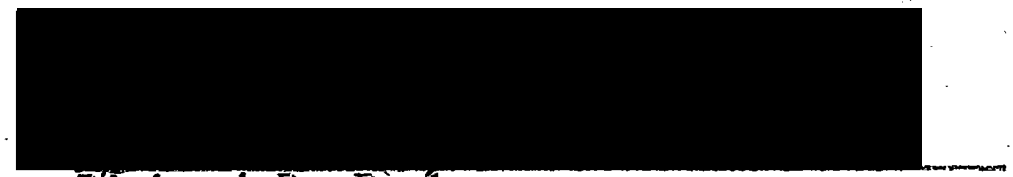

Richard $B$. Forbes

\section{APPROVED:}

Earl Fisher, Jr., Head, Departinent of Biology

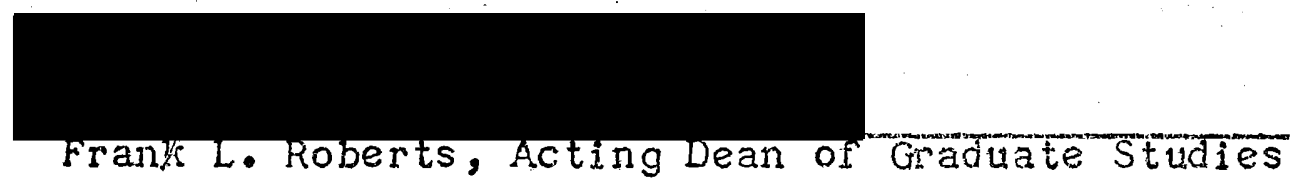

May 22, 1970 


\section{ACKNOWLEDGMENTS}

There are many people to whom I am profoundly grateful for the assistance they have given me in this thesis. I am especially indebted to Dr. Ralph W. Macy as my thesis adviser, for his help with the photographic work included in this thesis, and for his consistent encouragement; to Dr. Richard B. Forbes for his unstinting faith in me and my work and for advising me throughout my graduate program; to Dr. Earl Fisher, Jr., for his help in obtaining equipment for this study and for the support of an assistantship through his office; to Dr. Quentin Clarkson for his generous help in the statistical analysis of the data; to Dr. Robert P. Burns, from the Opthamology Department of the University of Oregon Medical School, for the loan of a slit lamp from his laboratory without which this study would not have been possible; and to Dr. Clyde I. Calvin for the use of his microphotographic equipment and his expert advice in processing the photographs. 
TABIE OF CONTENTS

PAGE

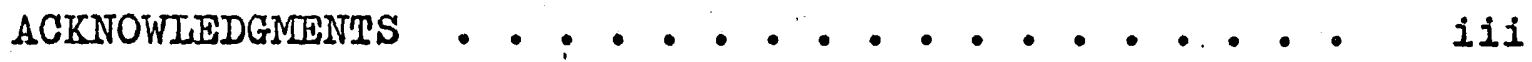

IIST OF TABIES •. • . . . . . . . . . • . . . . V V

IIST OF FIGURES • • • • • • • • • • • • • • • vii

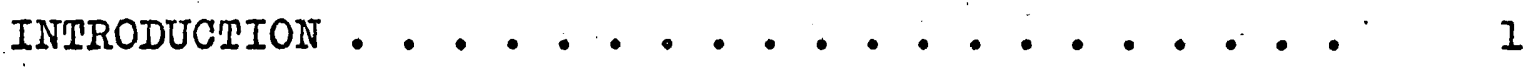

MATERIALS AND METHODS . . . . . . . . . . . . 12

RESUITS . . . . . . . . . . . . . . . . 20

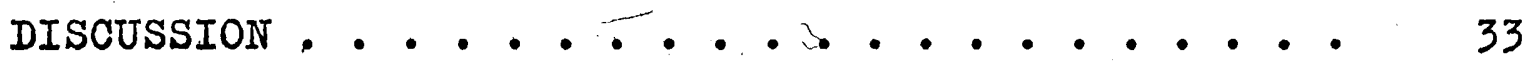

REFERENCES CITED . . . . . . . . . . . . . . 64

ADDITIONAI REFERENCES . . . . . . . . . . . 68 


\section{LIST OF TABLES}

TABI.E

PAGE

I Measurements of Demodex Foli iculorum

from Hirst (1919) . . . . . . 8

II Incidence of Demodex fol1iculorum in

Norma 1 and Disease States in Man. . 10

II All Periment Data From Nasal Area

Examinations . . . . . . . 21

IV Sex of the Host and the Incidence of

Demodex . . . . . . . . . 22

$V$ Coningency Chi-square Results from

Nasal Area Examinations . . . 23

VI Results from the Cheeks and Chin Viti1iz-

ing the Chemical sit Lamp Tech-

nique ..............

VII Results of Preliminary Eyelash. Test

Conducted on Selected Group wif

Forty Subjects . . . . . . 29

VIII Results from Epilating Eyelashes of

143 Subjects . . . . . . . 30

IX Results from squeezing Facial foliticles

of the Nose and Forehead Regions. . 30 
$X \quad$ Results from Pustule Contents of

Ingrown Hairs on the Neck ... - 31

$X I$ Results from Epilating Hairs from the

Chest and Pubic Areas ... . . 32

XII Results from Ear Wax Scrapings . . . 32

XIII Cases in Which Demodex folliculorum

Bears a Suspect Causal or

Cooperative Relationship • • • 59 


\section{LIST OF FIGURES}

FI GURE

PAGE

Drawings of Demodex fol1iculorum,

Demodex canis and Demodex bovis . -

Drawings of Demodex fol1iculorum Larva,

Nymph, and Adult, and Demodex canis . 6

Egg and Larvae of Demodex fol1iculorum . . 7

Views of the Eyelashes Showing Debris and

Collaring About Lashes Which is

Characteristic of Demodectic Infestation .................

Adult Demodex fol1iculorum Isolated from

Eyelash Fol1icle and Submerged in

Peanut Oi1 .......... 16

Wormlike Extrusions Forced Out of Sebaceous

Follicles of the Face By Squeering. Epilated Eyelash Showing Numerous Mites

Caught With Capitulums Buried Within

Root Tissue Near Base of Lash . . . 27. View of Eyelid Margin Showing Mites Partially Emerging Around a Lash After Swabbing With Ether ..... 28 
10 Comparison of the Ostia of Sebaceous

Follicles With the Openings of

Superficial Lanugo Follicles...

34

11 - Comparison of Deep Sebaceous Follicles

With Superficial Lanugo Follicles,

and The ir Corresponding Sebaceous

Glands . . . . . . . .

12 Epidermal Sheet Showing Two Adult Mites

in Infundibulum of a Sebaceous

Follicle . . . . . . . .

13. Capitulum of Demodex folliculorum from

Above $\bullet \cdot \cdot \cdot \cdot \cdot \cdot \cdot \cdot \cdot \cdot \cdot \cdot$

14 Capitulum of Demodex fol1iculorum from

Below $\bullet . . \cdot . \cdot . \cdot . \cdot . \cdot$ 


\section{INTRODUCTION}

Mites comprise a large and important group of Arthropods, although they are not we 11 known outside of the scienm tific world. Despite their obscure size, these Arachnids of the order Acarina are ubiquitous animals and Acarologists estimate the number of species to be at least one million. They have been found living on Mt. Everest, in hot water springs, on the walls of caves washed by seavater and some in the depths of deep freshwater we11s. A handful of fertile soil contains an average of five different forms (Baker and Wharton, 1952). Interest in these tiny creatures may be enhariced by knowing the nearest location of a representative of the mites - most likely on the end of tine nose or in the eyelash follicles of the reader. Mites may be free-living, saprophytic, or parasitic on plants and anima1s, as practically al1 living things serve as hosts. Some mamma 15 may have as many as five differerit mite forms as perasites on the same animai. Man is no exception and has been plagued by mites since the beginning of recorded history. There are five nain groups or families which comonly infest man with varied consequences.

Members of the family Dermanyssidae are bloodsucking mites normally found on birds and rodents. Some however, may temporarily become annoying himan pests in rat and mice 
infested buildings when orphaned by its normal hos ts being killed or ariven off. These mites play a minor role in transmission among reservoir hosts, and occasionally to man, of endemic typhus, rickettsialpox, $Q$ fever, tularemia, plague, and certain viruses.

Redbugs or chiggers are the six-legged larvae of mites of the family Trombiculidae which are parasitic on vertebrates but rree-living as nymphs and adults. These cause tremendous discomfort for many people due to allergic tissue reaction from the animal's iritating saliva that is superficially injected into the skin. A few closely related species of the genus Trombicula in the Far East are responsible for the transmission of scrub typhus, caused by Rickettsia tsutsugamushi, to man.

Many mites, most of them belonging to the families Acaridae (Tyroglyphidae) and Glycyphagidae, are common pests of human dwellings, stores, and warehouses where they attack all sorts of food materials, stored seeds, stuffings of furniture and other similar commodities. People who come into close association with infested goods develop symptoms which most workers feel are or an allergic nature. Though allergy undoubtedly plays a part, there is evidence that the bodies or excretions of the mites are toxic with both dermal and respiratory symptoms occurring.

The 1tch mites, Sarcoptes scabiei, members of the Sarcoptidae family, are well documented for the thin 
tortuous tunne is excavated by the impregnated female in the epidermis of man (Freidmai, 1942). The daily excavations of a female may appear as a grayish burrow due to the eggs and excrement she deposits along the way and amount to 2 or 3 millimeters in length. Transference to a new host occurs by actual contact, norma $11 y$ at night, rarely in the daytime, on account of the secretive habits of the mites. It is possible for infection to be derived from mangy animals, al though once adapted for several generations to a given host the mites do not often survive a transper to a different species of host for more than a few days (Johnson and Me 11 anby, 1942).

The last group concerns the family Demodicidae which now includes 3 genera and 43 known species and subspecies, all of which are apparently obligate parasites of mammals (see review by Nutting, 1964). Several demodicids are of concern to medical practitioners and veterinarians since they cause or are associated with marked pathologic conditions of man and domestic animals. One species in particular, Demodex folliculorum, the follicle mite of man, concerns the balance of this study.

Most species of Demodex are very sinilar and have been we11 illustrated by Hirst (1919). Demodex (from Gr. demos = fat, $d e x=$ worm) folliculorum is a tiny vermiform mite with an elongated abdomen which is ringed with striations giving an annular segmented appearance. The eight legs are short 
stumpy projections without setae. The legs have five segments and end in claws. Setae are also lacking on the body. The palpi are closely appressed to the tiny rostrum; the chelicerae are tiny and needlelike. The female genital opering is located ventrally between coxae IV and in the male the penis opens on the dorsal surface of the cephalothorax, slightly in front of the interval between the first and second legs. It is bipronged, one branch being strongly chitinised and acting as a sheath for the more delicately pointed division (Figures 1 and 2 ).

The egg of Demodex folliculorurn is approximately $0.08 \mathrm{~mm}$. in length by $0.04 \mathrm{~mm}$. in width (Gmiener, 1908). It is usually shield-shaped rather than ova1 (Figure 3 ). After hatching, the organism passes through larval, protonymph, deutonymph, and adult stages. The larvae have three pairs of legs which are poorly developer when compared with the adults (Figure 2). The adult has four paired appendages and is approximate $1 \mathrm{y} 0.3$ to $0.4 \mathrm{~mm}$. in lengti. All stages below adulthood are equally as long, but of ten more slender (Figure 2). Hirstis (19i9) measurements are given in Table I. Demodex follicuiorum was first seen and mentioned in. print by Henle in 1841. Freiedrich Gueiner (1908) however, credits the discovery of this animal to Berger, a Frenchman who found it in ear wax in 1842. However, neither of the initial discoverer's work came to light until after that of G. Simon (1842), who discovered the parasites independentiy 
5
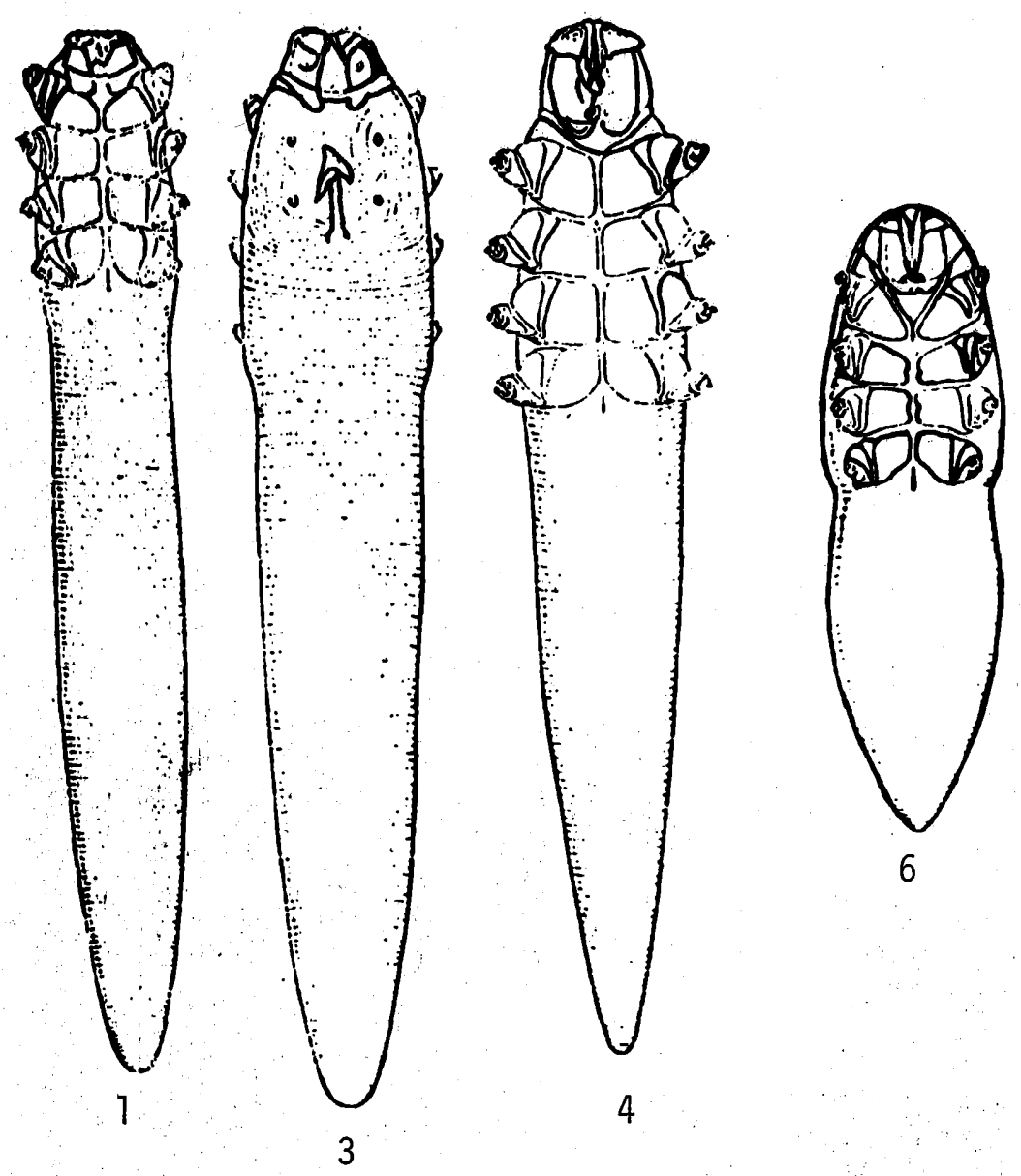

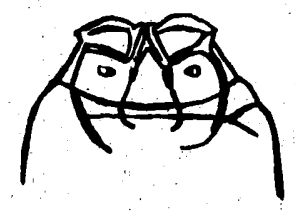

2

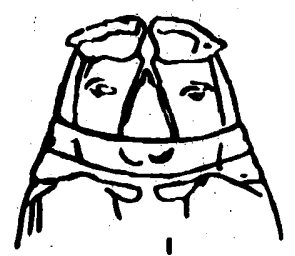

51

Figure 1. 1, Demode folliculorum (Simon), ventral view (X 345); 2, Demode folliculorum, capitulum from above; 3 , Demode folliculorum, dorsal view of male showing protruded penis; 4 , Demode can is (Leydig), ventral view (X 515); 5, Demodex cants, dorsal view of capitulum; 6 Demode boris (Stiles), ventral view. (From Horst, 1919) 


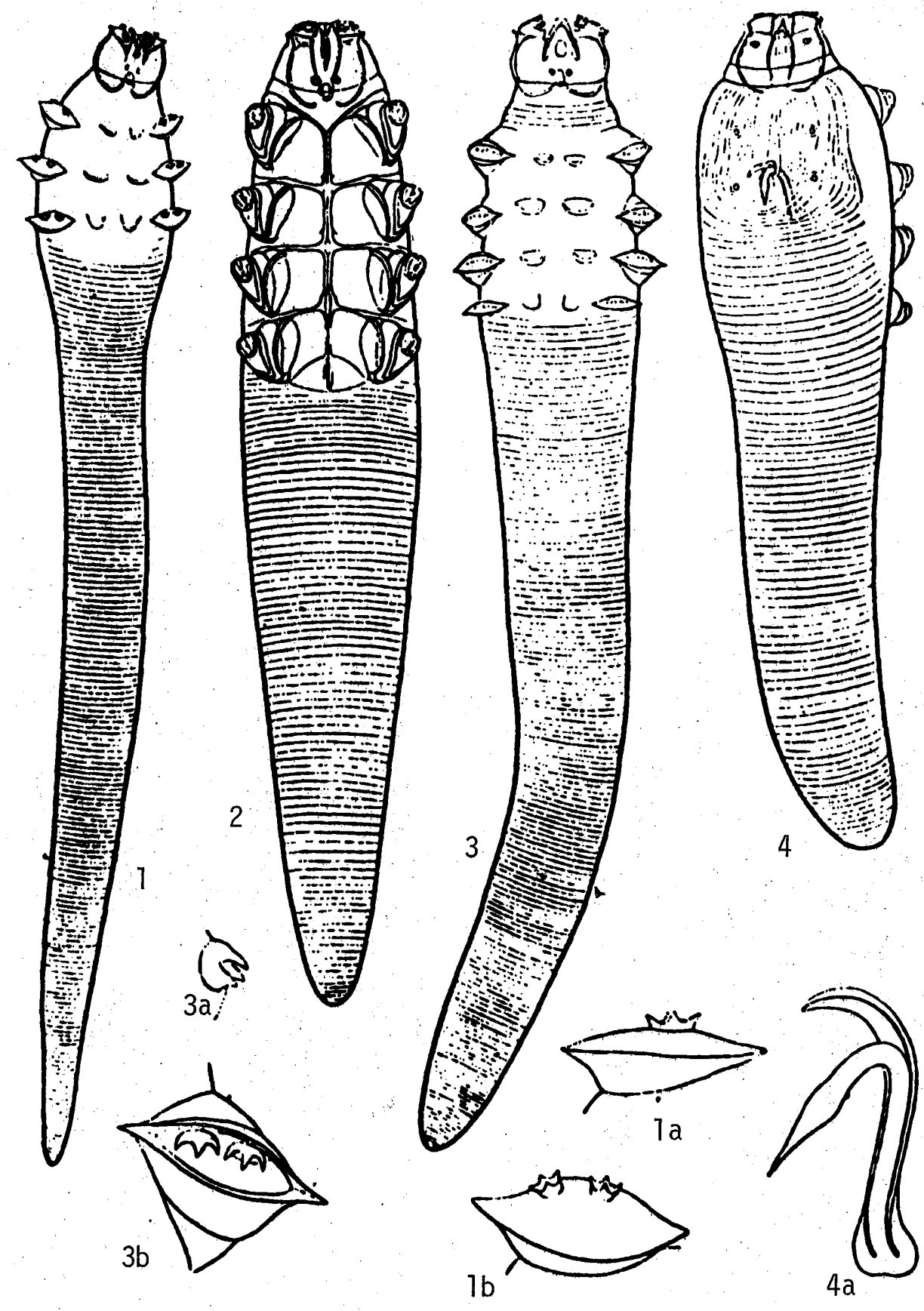

Figure 2. 1, Demodex folliculorum, elongated larval form, $1 \mathrm{a}$ and $1 \mathrm{~b}$, appendages of larval form; 2, Demodex canis var. ovis (Rai11); 3, Demodex folliculorum, elongated nymph, $3 a$ and $3 b$, appendages of nymph; 4, Demodex folliculorum, short form of adult male, $4 a$, penis greatiy en Targed. (From Hirst, 1919) 

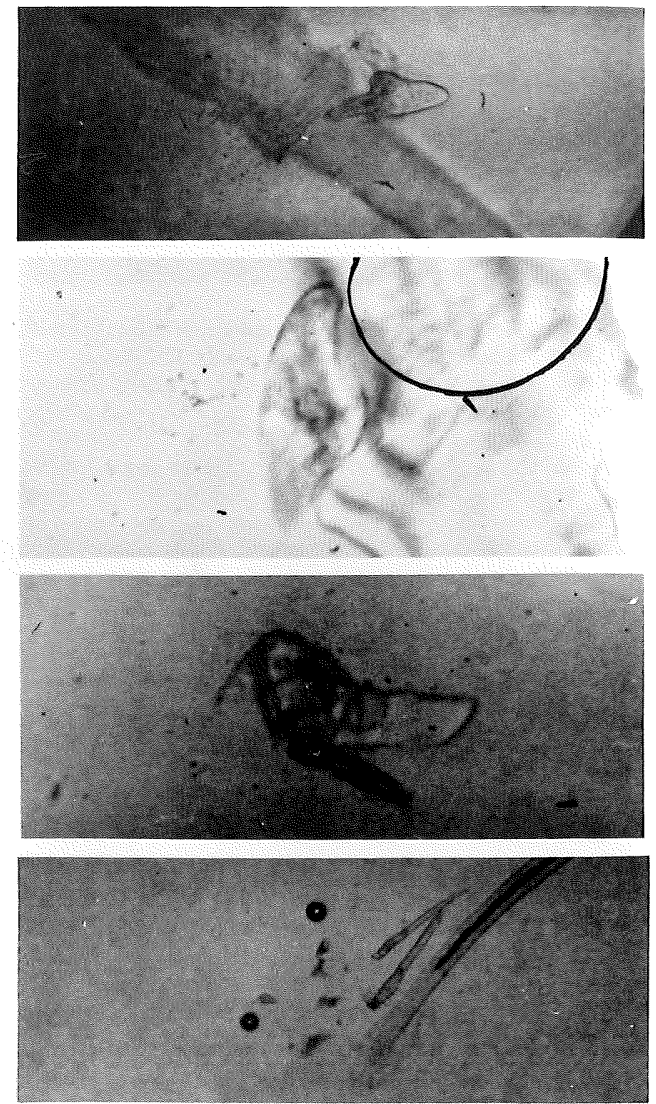

Figure 3. Demodex folliculorum. A, egg (approx.x60); B, egg ten minutes before hatching (approx. X240); C, larva with collapsed egg casing (approx. X60); D, immature forms (approx.X60). (From Coston, 1967) 


\section{TABLE I \\ MEASUREMENTS OF DEMODEX FOLLICULORUM \\ FROM HI TST (1919)}

Female Male

Total lengtin of body $2.70-440 \mu$

Length of cephalothorax + capitulum

$95 \mu$

Length of abdomen $\quad 170-340 \mu$

Greatest width of cephalothorax

Greatesi width of abdomen.

Greatest width of. capitulum

Length of capitulum

Length of spines on capitulum

$50-56 \mu$

$49-58 \mu$

$40 \mu$

$24 \mu$

$3 \mu$
Elongeted specimens $280 \mu$

Smail male with tail $170 \mu$

Sma11 male no tail $100-2.10 \mu$

$$
\begin{array}{r}
85 \mu 1 \\
200 \mu
\end{array}
$$

$47-50 \%$

$46 \mu$

$33 \mu$
$21-22 \mu$

33. 
in Berlin in his study of pathological findings of pimples. Simon published a good description of this parasite under the name of Acarus folliculorum, and stated that he found them in the follicles of the nose of all corpses except newborn babies. The generic name Demodex was created for it in 1843 by zoologist Richard Owen.

Demodex folliculor un (Simon, 1842) (the name reserved for the human parasite) may inhabit the follicles, with or without hair, anywhere on the body. It has a prediliction for the nose, chin, cheeks, outer ear canal, and margins of the eyelids although other parts of the body may be affected. Reported surveys show the incidence of infestation with this parasite ranges from $0.100 \%$. A detailed survey involving all the common sites of infestation had not been made in this country, and those of Europe were made over sixty years ago. Some publications state all adult humans harbor the organism, others say one half, and most are just as vague in assigning an accurate figure. Table II shows briefly the results obtained by early European biologists and illustrates the lack of concensus which in part helped to prompt this study. Essig (1958) said, "It is cosmopolitan but is rarely met with except in very unsanitary surroundings." Does hygiene play a role in its incidence? This is one question this study attempts to answer. Is Demodex found all over its generally reported habitats on man, or can selective sites be fould? Possible 
INCIDENCE OF DEMODEX FOLLICULORUM IN NORMAL AND DISEASE STATES IN MAN

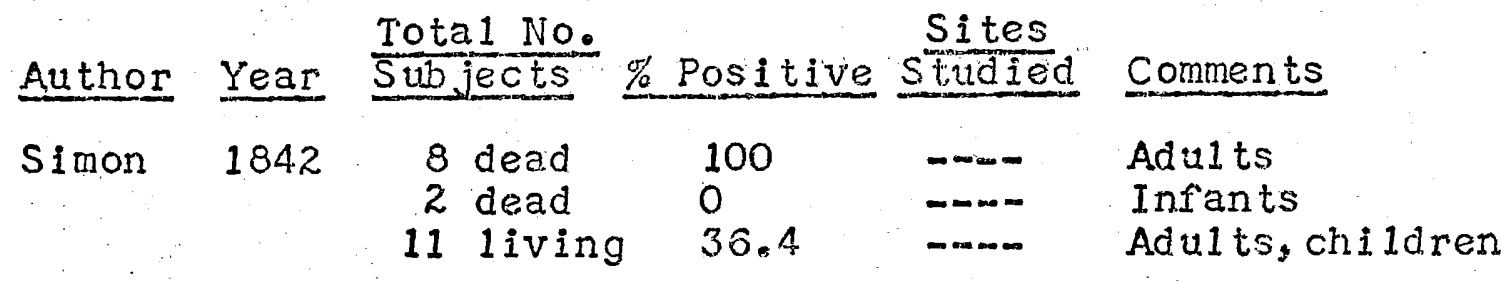

\begin{tabular}{|c|c|c|c|c|c|c|}
\hline Henle & 1845 & 12 & dead & 91.6 & $-\cdots-\infty$ & $-\cdots$ \\
\hline Gruby & 1846 & 60 & living & $66 . ?$ & $\ldots$ & $a-\infty$ \\
\hline Wils on & 1847 & $-m$ & Iiving & 100 & $-\infty m$ & $-m-\infty$ \\
\hline Leydig & 1859 & -- & living & 100 & $\because \infty$ & $---\infty$ \\
\hline Geber & 1884 & 200 & living & 100 & $\cdots \infty$ & $-m-\infty$ \\
\hline Megnin & 1892 & $-\ldots-$ & living & 10 & $-n$ & Soldiers \\
\hline Moniez & 1896 & $-\cdots$ & living & 10 & $-\infty-$ & Students \\
\hline Huns che & 1900 & 93 & living & 92.5 & $-\infty-$ & Children \\
\hline Guiart & 1902 & 10 & living & 100 & $-\cdots-$ & $-\infty$ \\
\hline Lando is & 1905 & 109 & living & 65.1 & $-\infty-\infty$ & $m-\cdots$ \\
\hline Gmeiner & 1908 & 100 & dead & $\begin{array}{l}97 \\
50 \\
61 \\
86 \\
49\end{array}$ & $\begin{array}{l}\text { Composite } \\
\text { Eyelids } \\
\text { Forehead } \\
\text { Nose } \\
\text { Chin }\end{array}$ & All ages \\
\hline DuBois & 1910 & $\begin{array}{r}200 \\
50\end{array}$ & $\begin{array}{l}\text { living } \\
\text { living }\end{array}$ & $\left\{\begin{array}{l}100 \\
0 \\
50 \\
100\end{array}\right.$ & $\begin{array}{c}\text { Face } \\
n\end{array}$ & $\begin{array}{l}\text { Ages } 20-85 \\
\text { Less than } 5 \\
5-10 \text { yrs. } \\
10-20 \text { yrs. }\end{array}$ \\
\hline
\end{tabular}


factors which might influence the incidence were a dry or oily (seborrheic) skin condition, the amount of facial hair, and the age and sex of the human host. A final question which proved to be difficult to answer was whether any contemporary patterns of incidence could be found which would indicate some trend in the distribution and habitat of this parasite since its discovery over a century ago.

The controversy surrounding this parasite as a possibie pathogen or vector of disease is explored in light of the current knowledge. The question of distinct species is discussed in an attempt to point out some new possibilities for future study and the evolutionary implications this strange family of mites reveals for workers in the field. 
MATERIAIS AND METHODS

Phototactic studies by Spickett (1961a) have shown that Demodex folliculorum avoids 1 ight and is undoubtedly a nocturnal creature. No one has reported seeing the organism on the surface of the sking and its location, headfirst within the folljcle, prohibits simple observation (Figure 4). A technique modjfied after coston (1967) was adopted to overcome this obstacle. The mites partial?y back out of lash follicles and facial follicles upon the brief application, 45-60 seconds duration, of a highly volatile stbstance (ether, chloroform, camphor, spinits of armonia, D.M.S.O., or acetone). After 3-5 ninutes I could see, with slit lamp magnification, tiny cream-colored, cylindrical-shaped objects, the posterior ends of mites, partially emerging from follicles. A cotton applicator saturated with acetone proved most acceptable to subjects while ether and chloroform were rejected as too noxious, especially for children and the elderly. Utilizing this technique various areas of the face were sampled including the nose, chin and cheeks.

Another source of sampling was the epilation of eyelashes. While waiting for the acetore to take erfect, the eyelashes of the subject were examined with the slit lamp. A characteristic fine, waxy, dry debris, often slighty 

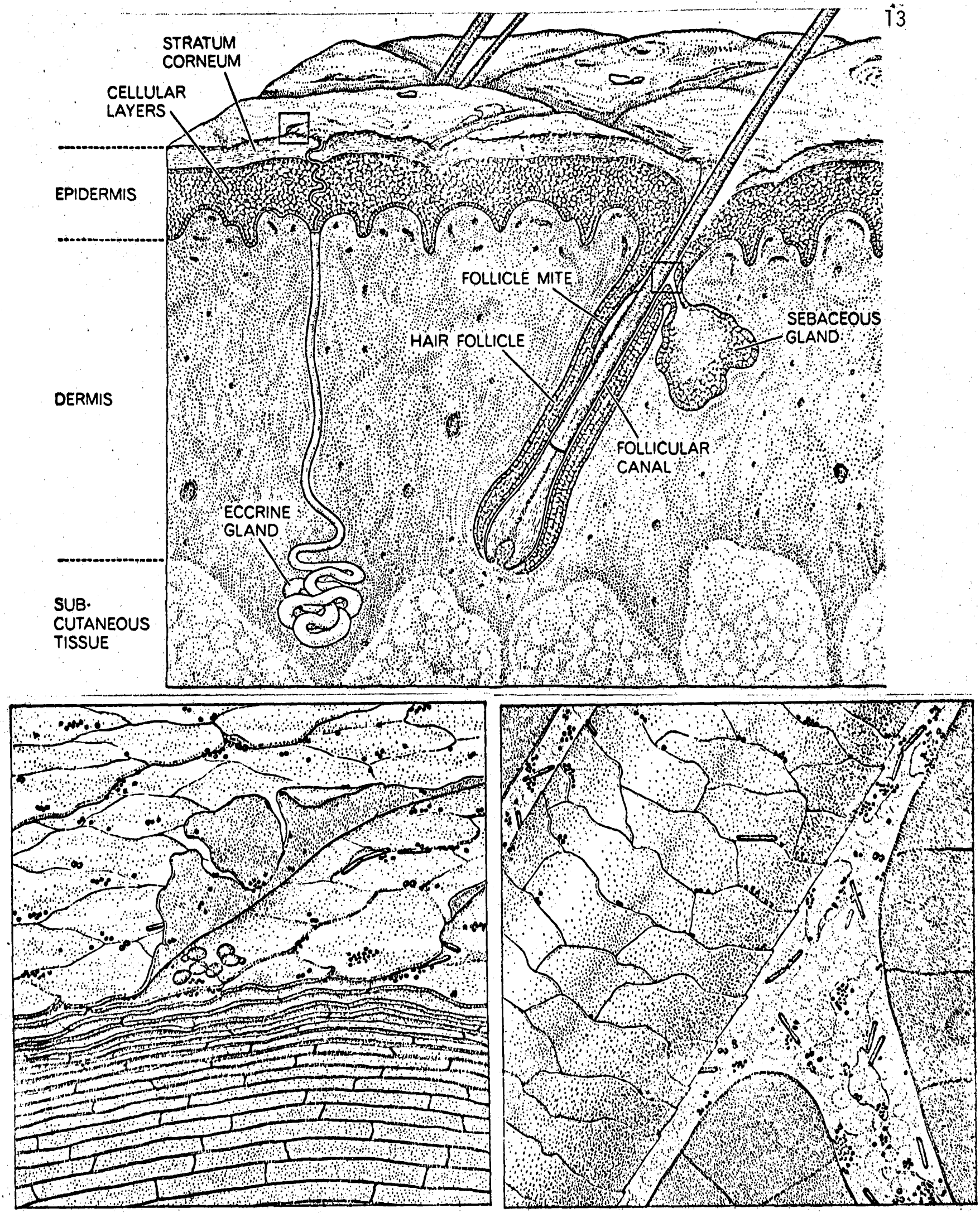

Figure 4. Habitat of Demodex folliculorum. Scarcely visible to the unaided eye, Demodex is $4^{\prime 00}$ times Targer than an average bacterium. The squares indicate regions that appear below enlarged about 1000 diameters showing bacterial and fungal cells on skin and within follicle. 
yellow in color, lying on the skin about the bases of the cilia could of ten be seen. A smooth transparent collar of mite feces surrounds some lashes for one to two millimeters as they emerge from the follicle, and appears to enlarge the orifice at the skin surface (Figure 5). This collar has the appearance of clear plastic insulation about the lash and when they were observed and attempt was made to epilate those lashes, if the subject was willing to cooperate. The lashes were placed in a drop of peanut oil on a glass slide with a coverslip and under the tnicroscope the mites are easily seen if present. Peanut oil or olive oil are best because the adult mites of ten imbibe some and live in such media for some time (Figure 6 ).

A third method for demonstrating the mites involved squeering the skin follicles of the face and examining the material extruded under the microscope. DuBois (1910), the first to employ this technique stressed the importance of examining the follicular material obtained after the second squeeze since the first material from the follicle mouth sometimes contained no mites. Often soft, yellowish or whitish wormlike extrusions are forced out of sebaceous follicles of the nose and forehead having the appearance and consistency of jelly or petrolatum (Figure 7). These are neither comedones nor sebum, but almost solid masses of Propionibacterium (K1igman and Shelley, 1958).

The discomfort of ingrown hairs on the area of the 


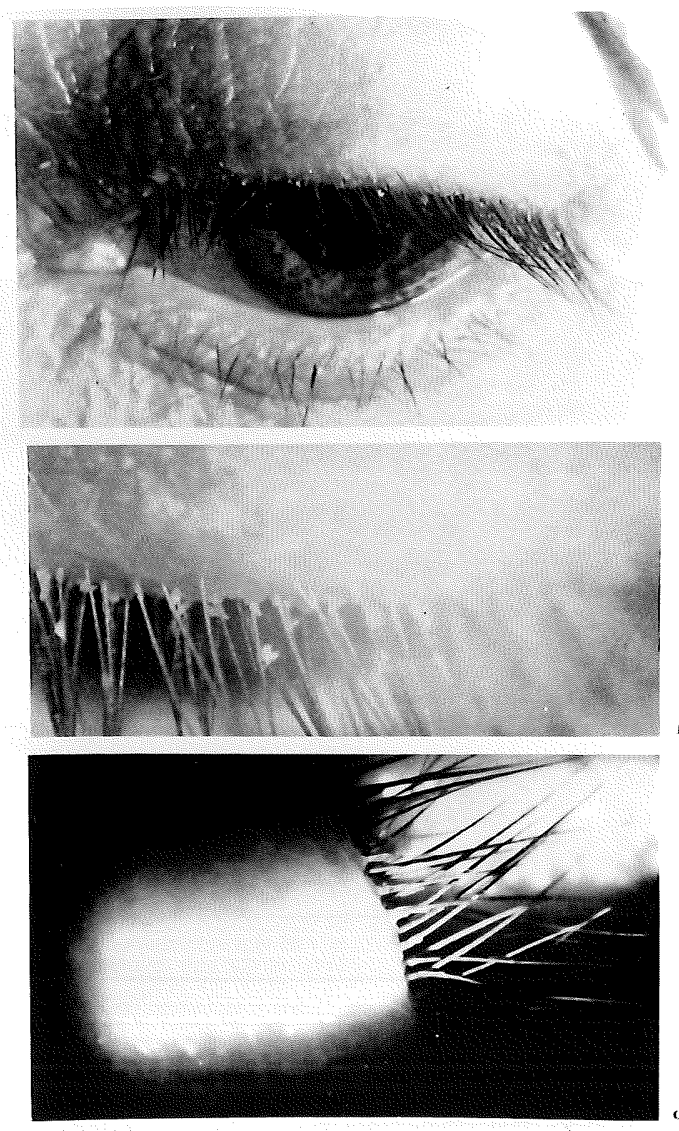

Figure 5. Views of the eyelashes showing debris and collaring about lashes which is characteristic of demodectic infestation. A, unaided view; B, slit lamp, low power; C, collaring about lashes, slit lamp, high power. (From Coston, 1967) 


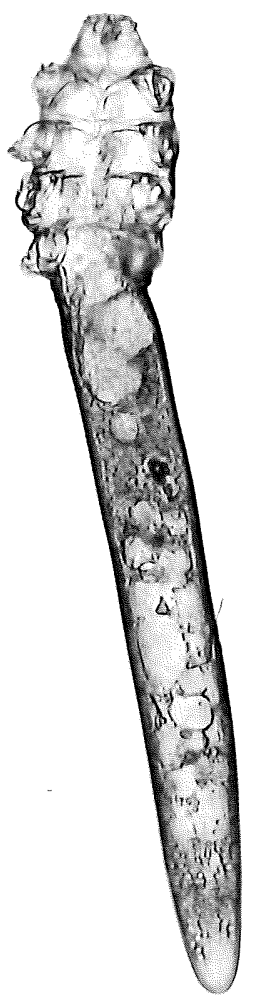

Figure 6. Adult Demodex folliculorum isolated from eyelash folTicle and submerged in peanut 017 (X 250). 


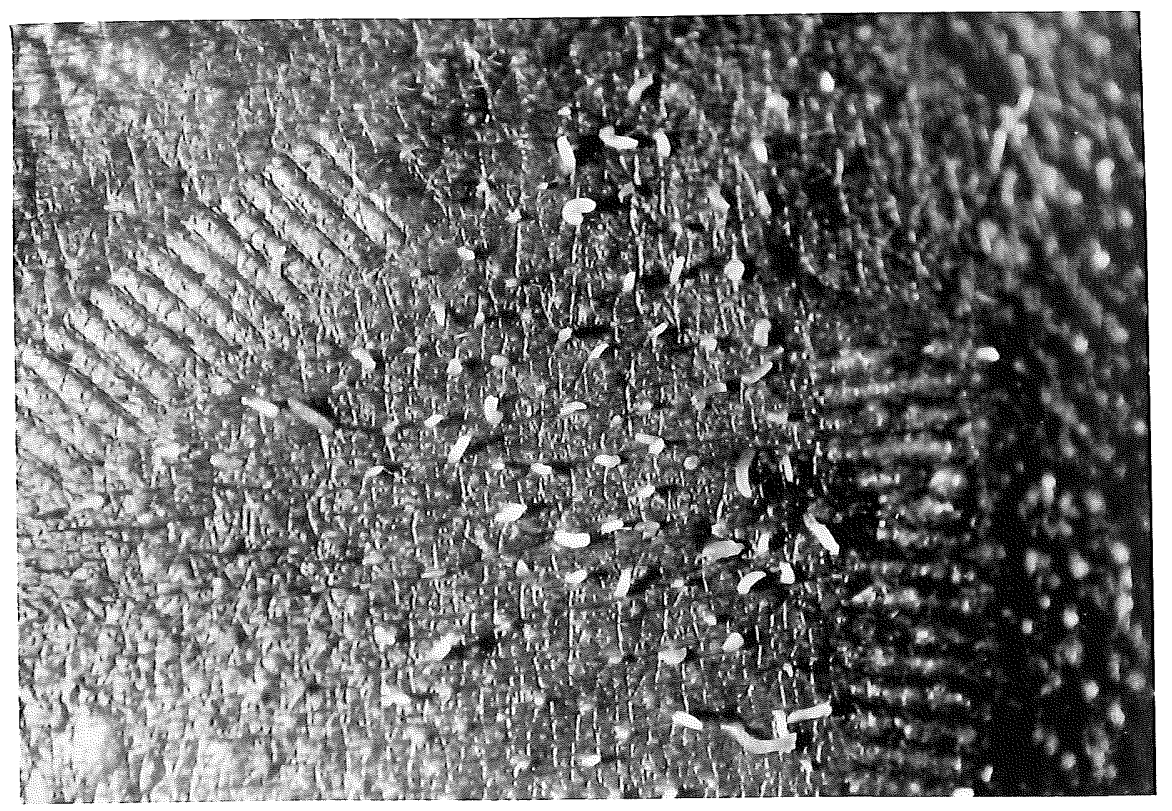

Figure 7. Worm-like extrusions forced out of sebaceous follicles of the face by squeezing. These have about the consistency and appearance of yellow petrolatum and a few can be found in most subjects. They are neither comedones nor sebum, but almost solid masses of Propionibacterium (X6). (From K1igman \& She11ey, 1958) 
neck shaved every day has plagued the author for about 7 years. Commonly an inflamed, pus-filled pimple forms at the site and upon examination of the material within the pustule, Demodex folliculorum was found. This comprised another sample group in this study.

Other sample areas utilized were the chest and pubic areas. In both cases hairs were plucked and examined under the microscope in a drop of peanut oil.

The final. source of material was ear wax. The wax was collected by gently rubbing a blunt metal probe around the opening of the auditory passage and placing the material. on a glass slide. By swirling the material in a few drops of xylene with a blunt probe a thin smooth iayer was obtained and after a coverslip was added, microscopic examination followed.

In analyzing the results of this study the Contingency Chi-Square test for independence was utilized. If we call the total nurnber of observations $N$, and the individual nutrerical contributions to this value $a, b, c$, and $d$, respectively, then the calculations are as follows:

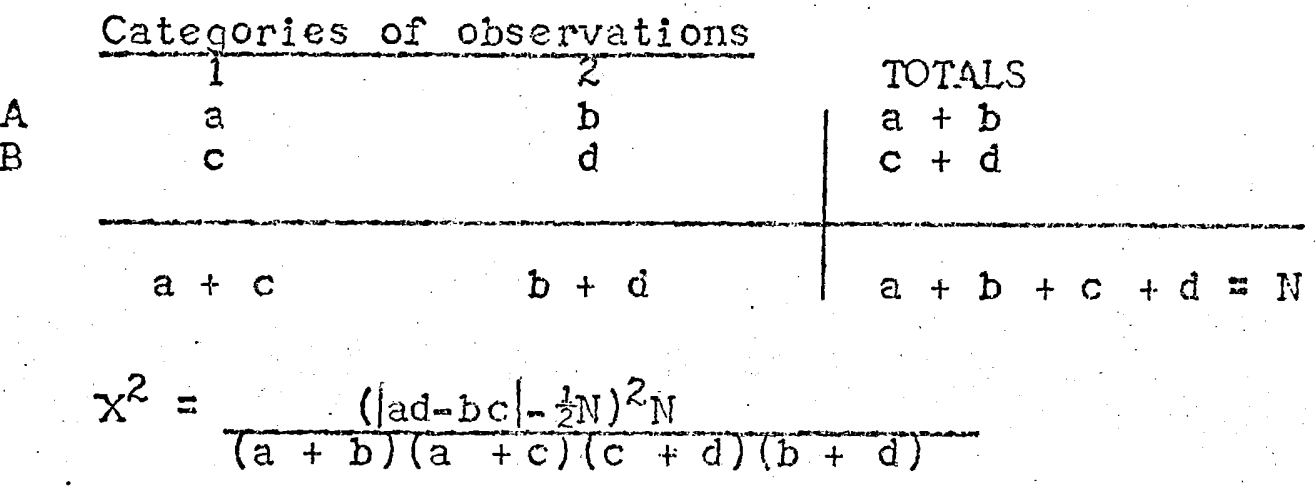


In an effort to obtain a wide range of age groupings subjects were solicited from a variety of institutions. It was also essential to have a large number of potential volunteers gathered in a single area before moving equipment to make the examinations. The types of organizations involved were public primary and secondary schools, rest and retirement homes, correctional institutions, and social rehabilitation and service centers. The faculty and students of Portland State University as well as family, friends, and "walk-in" volunteers were also utilized. 


\section{RESULTS}

Nasal Area. The earlier work of Gmeiner (1908) and DuBois (1910) in Europe indicated that the skin of the nose was a common site of Demodex infestation. This sample area was therefore utilized in ar attempt to correlate the incidence of mite infestation with the age, sex, skin condition, and amount of facial hair of the human host. In Table III a1i pertinent data has been compiled and a simple percentage of incidence has been computed for each of the five age groups. The sex of the human host was eliminated as a variable because there was no significant variation fron the expected results within each age group. The only excepm tion was in the oldest age group and here more women were infested than men. Testing for independence with a contingency chi-square, results showed statistical independence between the sex of the host and the presence of mites (Table IV). The chi-square value of 1.81 with one degree of freedom indicates independence. The amount of facial hair was also eliminated from consideration since the variance among hosts was suall and no valid quantitative method was found that could measure the differences. Thus we are left with three categories of pertinent information. The age of the hosi, which was broken down into five age groups, the condition of the shin, normal, dry or oily, and whether mites 
TABLE III

ALI PERTINENT DATA FROM NASAL AREA EXAMINATIONS

\begin{tabular}{|c|c|c|c|c|c|c|c|c|}
\hline Age & Skin & & $b j \in$ & cts & & osit & ve & Incidence \\
\hline & & $\mathrm{M}$ & & Tota 1 & $M$ & $E$ & Tota 1 & \\
\hline 8 & orma 1 & 15 & 17 & 32 & 1 & 0 & 1 & \\
\hline
\end{tabular}

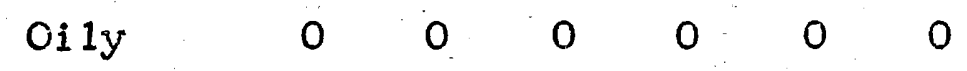

Dry $\quad 0 \quad 0 \quad \underline{0} \quad 0 \quad 0 \quad \underline{0}$

Group Tota1 $\quad 32=3.1 \%$

$\begin{array}{llllllll}9-17 & \text { Norma1 } & 10 & 12 & 22 & 5 & 2 & 7\end{array}$

$\begin{array}{llllllll}\text { Oily } & 12 & 7 & 19 & 1 & 1 & 2\end{array}$

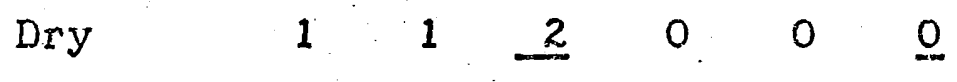

Group Tota1

$43 \quad 9$

$=20.9 \%$

\begin{tabular}{|c|c|c|c|c|c|c|c|c|}
\hline $18-30$ & Norma 1 & 35 & 4.4 & 79 & 12 & 21 & 33 & \\
\hline & Oily & 15 & 6 & 21 & 8 & 6 & 14 & \\
\hline & Dry & i1 & 8 & 19 & 2 & 2 & 4 & \\
\hline Group & Total & & & 119 & & & 51 & $=42.9 \%$ \\
\hline $31-50$ & Norma 1 & 29 & 43 & 72 & 16 & 20 & 36 & \\
\hline & Oily & 10 & 7 & 17 & 5 & 4 & 9 & \\
\hline & Dry & 1 & 6 & 7 & 0 & 1 & 1 & \\
\hline Group & Tota1 & & & 96 & & & 46 & $=47.9 \%$ \\
\hline $51-90$ & Norma 1 & 33 & 26 & 59 & 21 & 16 & 37 & \\
\hline & Oily & 25 & 31 & 56 & 15 & 23 & 38 & \\
\hline & Dry & 8 & 28 & 36 & 2 & 20 & 22 & \\
\hline Group & Tota 1 & & & 151 & & & 97 & $=64.2 \%$ \\
\hline
\end{tabular}


TABLE IV

SEX OF THE HOST AND THE INCIDENCE OF DEMODEX

\begin{tabular}{cccccc}
\hline Age & \multicolumn{2}{c}{ Males } & \multicolumn{2}{c}{ Fernales } & Total \\
\hline $1-8$ & 1 & 14 & 0 & 17 & 32 \\
$9-17$ & 6 & 17 & 3 & 17 & 43 \\
$18-30$ & 22 & 39 & 29 & 29 & 119 \\
$31-50$ & 21 & 19 & 25 & 31 & 96 \\
$51-90$ & 38 & $\frac{28}{117}$ & $\frac{59}{116}$ & $-\frac{26}{120}$ & $\frac{151}{41}$ \\
& 88 & & & &
\end{tabular}


were present were the final variables considered.

In order to deternine whether or not there was a correlation between the age, skin condition and presence of mites chi-square values were calculated for all combinations of variables. In these cases there are no definite expected values; the question is whether the results are dependent (contingent upon) or independent of the conditions under which they are observed. The statistical manipulation involving three categories of data in a test for independence is described in Kendall and Stuart, (1966). As shown in Table $V$ contingency chi-square values were first calculated for the three possible combinations of data i.e., skin conditions $x$ infestation, skin conditions $x$ age, and age $x$ infestation.

TABLE V

CONTINGENCY CHI-SQUARE RESULTS FROM NASAL AREA EXAMINATIONS

Categories Degree Free. Chingqure Significance

\begin{tabular}{lrrl}
\hline Skin $\times$ Inf. & 2 & 7.6190 & Dependence \\
Skin $\times$ Age & 8 & 84.6429 & Dependence \\
Age $\times$ Inf. & 4 & 55.3299 & Dependence \\
Skin $\times$ Inf. X Age & 29 & 169.3816 & $\begin{array}{l}\text { Dependence- } \\
\text { Partitioning }\end{array}$
\end{tabular}

Then a table was constructed for skin conditions $x$ age $x$ infestation. This involved five age groups, three skin conditions, and two units for infested or uninfested, a 
$5 \times 3 \times 2$ matrix with thirty expected values to compute in the contingency table. These row by colum by layer tables enable a partitioning of the chi-square values so that the chi-squares of the three $2 \times 2$ tables were subtracted from the large $5 \times 3 \times 2$ chi-square. The degrees of freedom are adjusted by subtracting in the same manner:

$$
\begin{aligned}
& x^{2}=169.3816-55.3299-84.6429-7.6190=21.9898 * \\
& \text { Degrees of Freedom }=29-4-2-1-8-2-4=8 \text { * }
\end{aligned}
$$

The final chi-square value, 21.9898 with 8 degrees of freedom is too large to show statistical independence, therefore we may conclude that there is a statistical dependence between the skin condition and age of the human host and infestation with Demodex folliculorum.

Having established a statistical dependence between these three categories we can now interpret the data as it is presented in Table III. First, there is a definite increase in the incidence of Detrodex folliculorum with the advancing age of the human host. Secondly, the normal and oily skin conditions are favored over the dry state throughout each of the first four age groups. The exception is in the oldest age group and here all three skin conditions show similar numbers of positive cases. The biological aspects of this interdependency will be presented in the discussion portion of this paper.

Cheeks And Chin. Results of mite infestation from these two areas are shown in Table VI. 
TABLE VI

RESULTS FRON THE CHEEKS AND CHIN UTILIZING THE

CHEMICAI-SIIT LAMP TECHNIQUE

\begin{tabular}{llllllll} 
Age Range & \multicolumn{3}{c}{ Subjects } & \multicolumn{2}{c}{ Cheeks } & \multicolumn{3}{c}{ Positive } & Incidence \\
$1-82$ & Total & $M$ & $F$ & Tota1 & \\
23 & 18 & 41 & 11 & 6 & 17 & $41.4 \%$
\end{tabular}

\begin{tabular}{lllllll} 
Age Range & \multicolumn{3}{c}{ Subjects } & \multicolumn{2}{c}{ Chin } & \multicolumn{2}{c}{ Positive } & Incidence \\
\hline 16 & Tota1 & $M$ & $F$ Tota1 & \\
\hline 16 & 9 & 25 & 4 & 2 & 6 & $24.0 \%$
\end{tabular}

Althougho statistical verification was attempied for these two areas the intended conclusions are clear. First, these areas of the face are involved along with the nasal area and this helps support the contention that the face does serve as the habitat of optimum occurrence. Secondly, although numbers are too small for statjstical verification, further studies may show a truly lower incidence for the chin and cheeks in comparison with the rasal area or in fact a similar pattern. Finally, this brief survey did serve to illustrate that selective sites may be involved in Demodex infestation for as yet unknown reasons. In some subjects the nasal area was involved, yet no mites could be found on other areas of the face, and in others the reverse was true.

Eyelashes. The second source of sampling, epilated eyelashes, was undertaken to see if there was once again any correlation between the age of the host and the presence 
of mites. The condition of the skin was not considered in this data because the eyelash pollicles and their specialized sebaceous glands comprise a somewhat isolated system, independent of the condition of the facial follicles. The validity of this sampling method comes under suspicion when one considers that only those mites which hold on tight enough to the lash, or are caught at the base of the lash, with heads buried within the root tissue (most common), will be detected with this technique (Figure 8 ). Of course, any stages within the pi io-sebaceous canel or sebaceots gland itself will most $11 \mathrm{kely}$ remain undetected, although on two occasions eggs were found on epilated lashes. Some workers (Smith and McCulloch, 1969) have had good results by vigorous $1 y$ rubbing the 1 id margins with an ethermsaturated cotton applicator prior to epilating lashes. The most valid method of diagnosis would seem to be examination with the slit lamp after ether swabbing to observe mites which have partially emerged from the follicles (Figure 9). However, the latier two methoos involve the application of a topical anaesthetic to the eye by a qualified physician. In order to overcome the problem of validity with this sampling technique a preliminary test was conducted on a group of 40 subjects at a retirement home for the elderly. The results of this test are shown in Table VII. On the first visit two eyelashes were epilated from each 1 id at random and examined for mites. Eleven of the forty subjects were found positive for the presence of mites. 


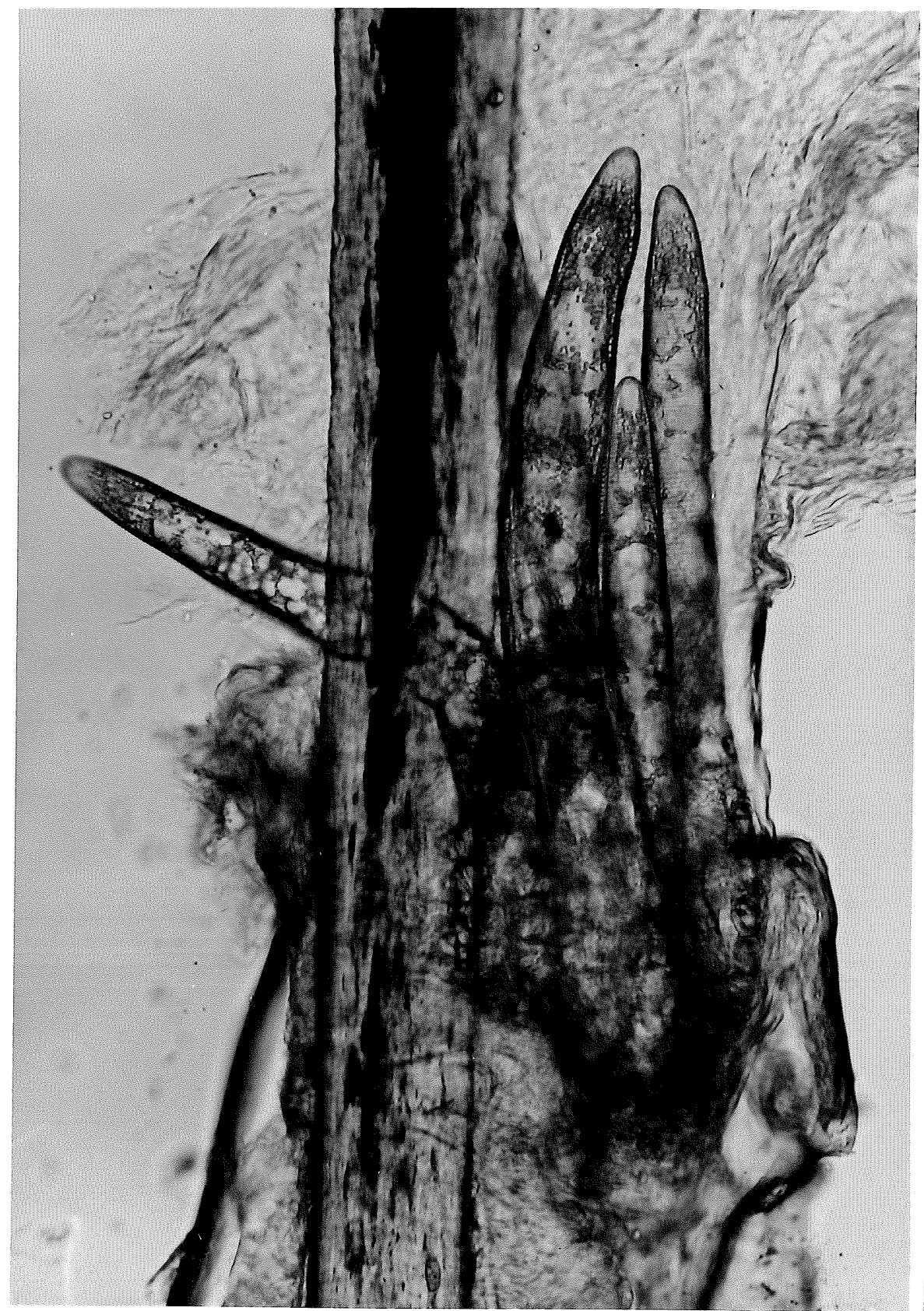

Figure 8. Epilated eyelash showing numerous mites caught with capitulums buried within root tissue near base of lash. Six mites were found on this one eyelash ( $X 310)$. 


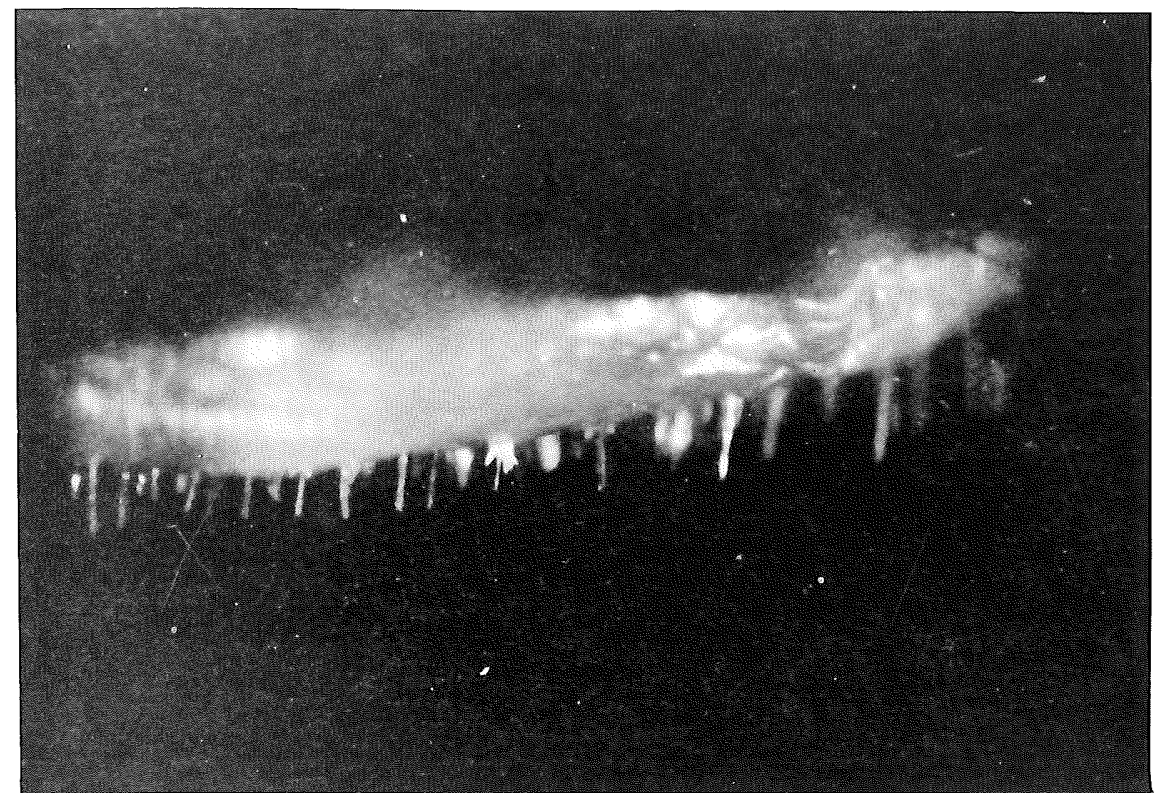

Figure 9. View of eyelid margin under slit lamp high power magnification showing mites partially emerging (center) around a lash after ether swabbing. (From Coston, 1967) 
TABLE VII

RESULTS OF PRELIMINARY EYELASH TEST CONDUCTED ON SELECTED GROUP OF FORTY SUBJECTS

40 Subjects

Age Range

$58-90$
Random

Dec. 20, 1969

$11+$
Co11ars

Jan. 3,1970

$26+$

On a subsequent visit two weeks later the same forty subjects were again examined, but this time the lid margins were examined with the slit lamp prior to the epilating of 1ashes. On $1 \mathrm{y}$ those lashes exhibjting the characteristic transparent collar of mite feces or having fine, waxys dry debris at their bases, were epilated. The number of positive cases increased to 26 including 8 of the first 11 and 18 new cases. This would seem to support Coston's (1967) contention that the collar aboul the base of a lash is pathognomonic for the presence of mites in that follicle. The results shown in Table VIII were obtained utilizing a preference for collared lashes wher they were found. There is a definite increase in incidence with the advancing age of the host and a contingency chi-square value of 31.9122 with 4 degrees of freedom indicates a lack of independence. Thus there appears to be a statistical dependence between the age of the human host and the presence of Demodex folliculorgm in the eyelash follicles. Again it should be stated that selective sites could he found on some subjects. 
TABI.E VIII

RESULTS FROM EPILATING EYELASHES OF

143 SUBJECTS

\begin{tabular}{lrrrrrrr} 
Age & \multicolumn{3}{c}{ Subjects } & \multicolumn{3}{c}{ Posjtive } & Incidence \\
\hline $1-8$ & 3 & 2 & 5 & 0 & 0 & 0 & $0 \%$ \\
$9-17$ & 12 & 6 & 18 & 3 & 0 & 3 & $16.7 \%$ \\
$18-30$ & 21 & 11 & 32 & 10 & 4 & 14 & $43.7 \%$ \\
$31-50$ & 13 & 16 & 29 & 5 & 7 & 12 & $41.4 \%$ \\
$51-90$ & 36 & 23 & $\frac{59}{14}$ & 28 & 15 & $\frac{43}{72}$ & $72.8 \%$ \\
& & & 143 & & & 72 &
\end{tabular}

The presence of Demodex in. the eyelash follicles for instance did not necessarily mean the subject's facial pores were involved, and sinilarly, the reverse was often true.

Squeezing Facial Follicles. The results of the third method, squeezing facial follicles, are shown in Table IX.

TABLE IX

RESULTS FROM SQUEEZ,ING FACIAL FOLIICLES OF THE NOSE AND FORELEAD REGIONS

\begin{tabular}{|c|c|c|c|c|c|c|c|}
\hline \multirow{2}{*}{ Age Range } & \multicolumn{6}{|c|}{ Nose } & \multirow[b]{2}{*}{ Incidence } \\
\hline & $M$ & $\mathrm{abj}$ & ts & $M$ & $s \frac{i}{F}$ & Total & \\
\hline $12-78$ & 21 & 13 & 34 & 5 & 2 & 7 & $20.6 \%$ \\
\hline \multicolumn{8}{|c|}{ Forenead } \\
\hline $12-78$ & 19 & 17 & 36 & 4 & 1 & 5 & $13.9 \%$ \\
\hline
\end{tabular}

This technique was used in the nasal area and forehead regions of a limited number of subjects unili it became 
apparent that the results were below expected levels as determined with the chemical and slit lamp method. This was the principle means of sampling used by all of the early workers in Europe and might indicate a trend in the incidence pattern for this parasite which will be discussed later in the paper.

Ingrown Hairs. Ingrown haje on the neck comprised a small sample group of exclusively men (Table $X$ ).

\section{TABLE $X$}

RESULTS FROM PUSTULE CONTENTS OF INGROWN HA.IRS ON THE NECK

\begin{tabular}{|c|c|c|c|c|c|c|c|}
\hline \multirow{2}{*}{ Age Range } & \multirow{2}{*}{\multicolumn{3}{|c|}{ Subjects }} & \multicolumn{3}{|c|}{ Positive } & \multirow[t]{2}{*}{ Incidence } \\
\hline & & & & $\mathrm{M}$ & $F$ & Tota 1 & \\
\hline 17.41 & 13 & 0 & 13 & 5 & 0 & 5 & $38.4 \%$ \\
\hline
\end{tabular}

Although Breckenridge (1953) reported examples of ingrown hairs in skin sections in which Demodex were observed, the results in this study serve to support his contentions as well as indicate a new clinical entity involving this organism. Its possible role in the formation of ingrown hairs will be stated in the discussion.

Chest And Pubic Areas. Very smal1 numbers of subjects were found for sampling the chest and pubic areas, and therefore little can be said of the results (Table XI). Although a physician's office would seem to be a much better place for volunteers, such facilities were not availble. 
TABLE XI

RESULTS FROM EPILATING HAIRS FROM THE CHEST AND PUBIC AREAS

\begin{tabular}{llllllll} 
Age Range & \multicolumn{3}{c}{$\begin{array}{c}\text { Subjects } \\
\text { Suest }\end{array}$} & \multicolumn{3}{c}{ Positive } & Incidence \\
$17-69$ & 16 & 2 & 18 & 0 & 0 & 0 & $0 \%$
\end{tabular}

Pubic Area

$\begin{array}{lllllll}19-28 & 12 & 2 & 14 & 0 & 0 & 0\end{array}$

Ear Wax. The final set of results involves the findm ings from ear wax samples (Table XII). Again the number of subjects is sma11, but sufficient for the purpose of demoriw strating that this is not an uncommon site of infestation, although with this technique the mites are easily overlooked and difficult to collect.

\section{TABLE XII}

RESULTS FROM EAR WAX SCRAPINGS

\begin{tabular}{llllllll} 
Age Range & \multicolumn{2}{c}{ Subjects } & \multicolumn{3}{c}{ Positive } & Incidence \\
\hline $18-69$ & 17 & 3 & 20 & 4 & 0 & 4 & $20.0 \%$
\end{tabular}




\section{DISCUSSION}

Nasal Area, Chin, Cheeks. In man, sebaceous glands vary widely in size, but are largest and nost numerous in the scalp, forehead, cheeks, nose and chin, where 400 to 900 of them may be found in each square centimeter of skin surface (Montagna, 1962). Usualiy, although not necessarily, sebaceous glands are joined to hair follicles forming a pilowsebaceous unit. The ducts of the glands, called pilo-sebaceous canals, open directly into the hair canals so that sebum is extruded onto and around the hairs. There are two types of pilomsebaceous units in the glabrous skin of the face (Figure 10). The most numerous are tiny and supericial, generaliy not extending more than $0.75 \mathrm{~mm}$. beneath the surface (K1igman and Shelley, 1958). With the naked eye, their ostia and minute hairs are all but invisible, but under slit lamp magnification they are easily seen. These lanugo follicles have characteristic and disproportionately large sebaceous glands, but slit lamp examination revealed that Demodex are rarely found in these follicles. The less numerous units whose ostia are easily visible to the naked eye are called sebaceous follicles and are practically limited to the adult facial skin (K1igman and Shelley, 1958). The gaping orifices were highly prominent in many oily subjects, 


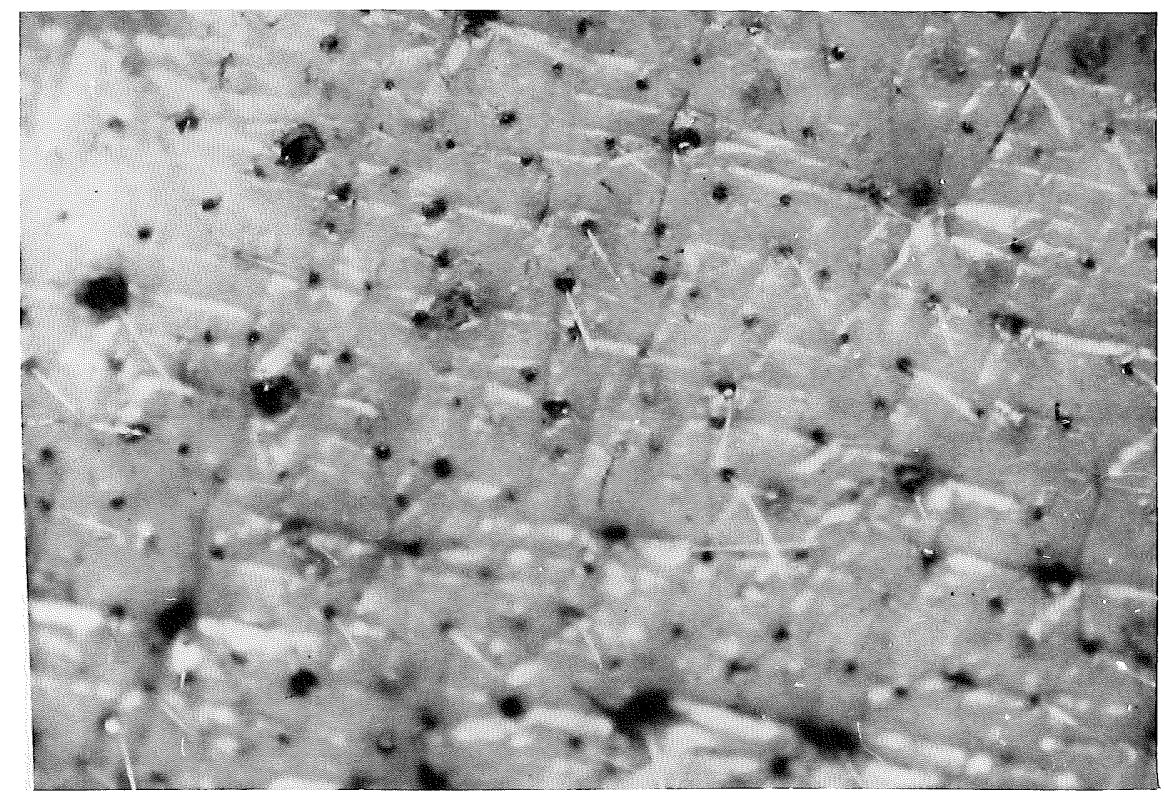

Figure 10. Comparison of the ostia of sebaceous follicles with the openings of superficial lanugo follicles. The larger black spots mark the ostia of sebaceous follicles while the smaller dots indicate the openings of lanugo follicles. The latter are more numerous and their associated hairs are generally too tiny to be visible (X10). (From Kligman and Shelley, 1958) 
especially on the cheeks and nose. These sebaceous follicles have multilobular, spreading sebaceous glands of extravagant size and depth, enormously greater in volume than the much smaller glands of the superficial lantugo follicles (Figure 11). The huge gland empties to the surface through a wide duct which is in fact the follicle, and here Demodex could be seen partially emerged from the effect of the acetone or ether application when vieved through the slit lamp. Although large terminal hair follicles were often infested, the mites were found most frequently in the sebaceous follicles characterized by their spacious infundibula into which the products of many sebaceous glands empty. A relatively tiny hair of insignificant proportions and its follicle are reduced to mere appendages of the sebaceous gland, instead of the gland being an appendage of the external root sheath of the hair foilicie (K1igman and She1.1ey, 1958). Although outrumbered by the tiny superficial hair follicles by a ratio of $3: 1$, the sebaceous follicles serve as the important habitat of Demodex fol1iculorum and their distribution coincides with the parasite's distribution on the skin of the face of man (Figure 12).

The size of sebaceous glands and their rate of secretion of sebum varies markedly with age. In newborn infants, sebaceous glands are large, but they become small shortly after birth, and remain small through infancy and childhood. 


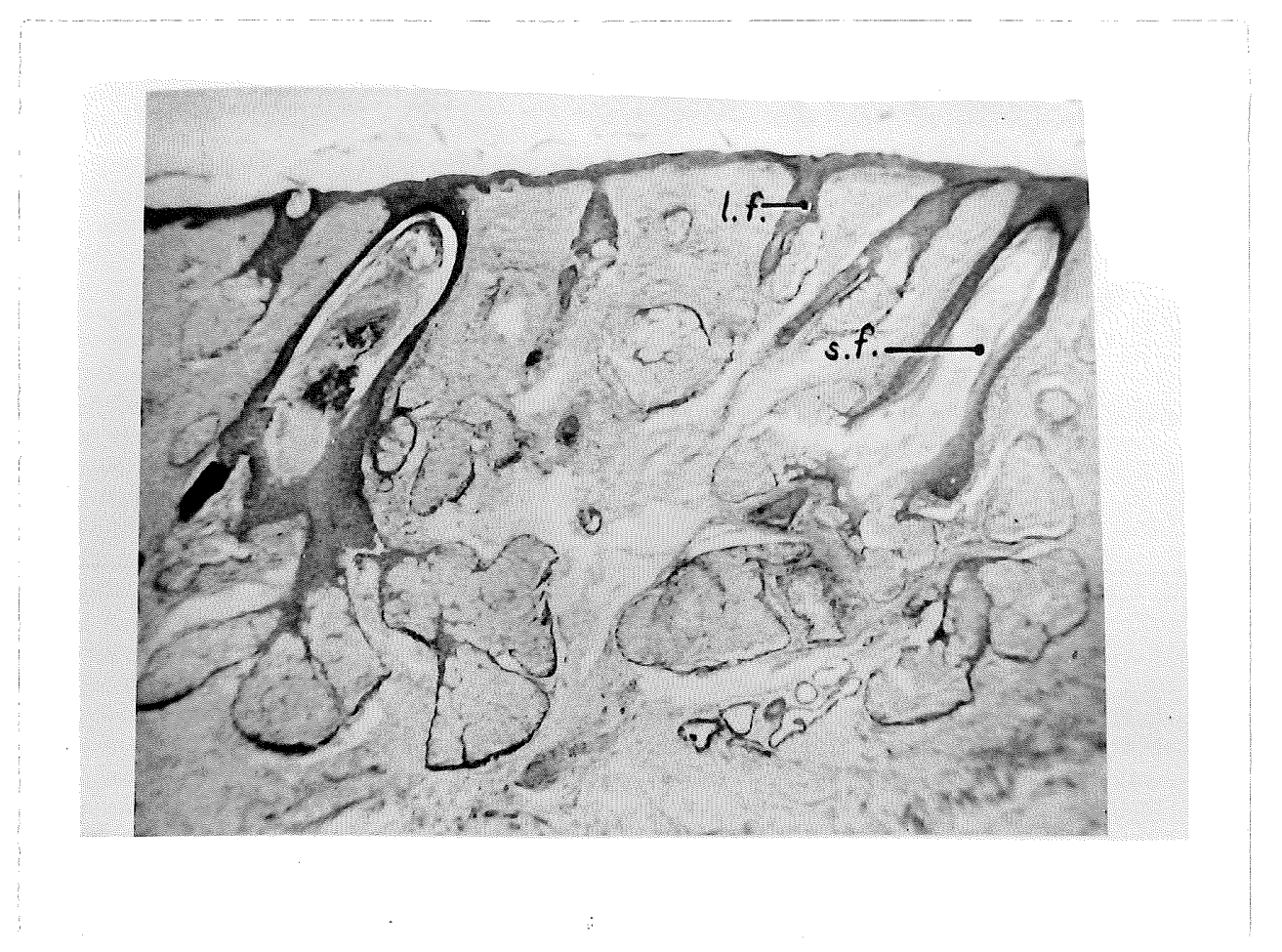

Figure 11. Comparison of deep sebaceous follicles (s.f.) with superficial lanugo follicles (1.f.). Note large lumen of sebaceous follicle and the extravagant size of their attached glands. This section contains two sebaceous follicles and four superficial lanugo follicles (X34). (From Kligman and Shelley, 1958) 


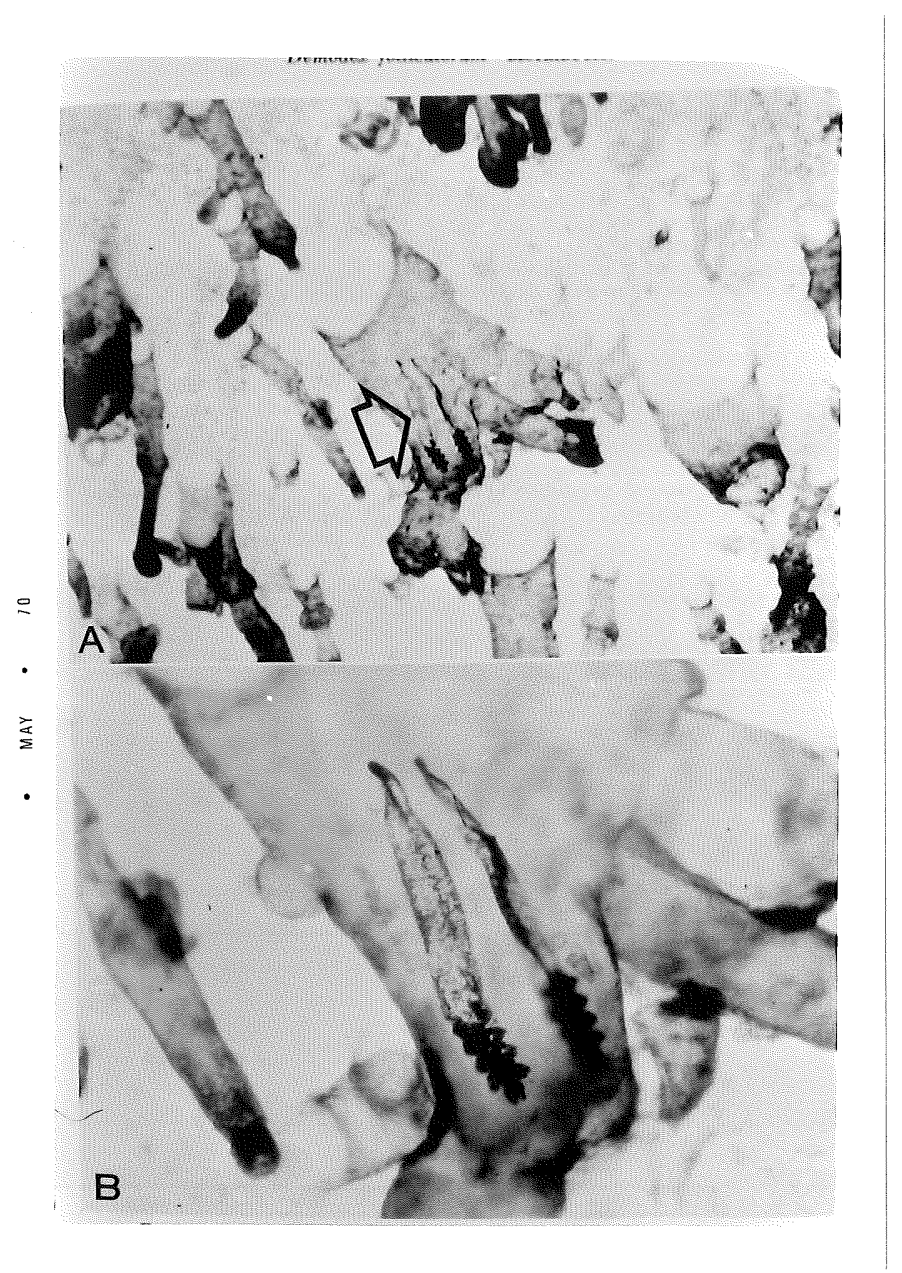

Figure 12. A, Epidermal sheet showing two adult mites in the infundibulum of a sebaceous follicle $(\times 6)$; $B$, same follicle, (X18). (From Riechers and Kopf, 1969) 
They are fully developed by the onset of puberty (Montagna, 1962). Sebaceous secretion in the newborn baby is high, even when measured one week after removal of the vernix caseosa. On the other hand the values obtained in the examination of children between the ages of 2 and 12 years are only one-third to one-half of those found in adults (Emanue 1, 1936). Boys and girls between the ages of 13 and 16 show a somewhat higher lipid secretion than in the younger children, but lower than the average value observed. in adults (Kirk, 1948). The total amonnt of lipid secreted in a twe lve hour period is approximately the same in adujt men and wonen until the age of $\%$. After this age the sebaceous secretion remains high in men and even shows $a$ tendency to increase, whereas the values for wonen in the age group 70-100 years are much lower than those found in men (Kirk, 1948). By this age however, women are "foritiym ing" their facial noisture by substituting cold creams for soap and water and these cosmetic cleansers do not remove the sebum from the pores.

Applying these fiats to the results in Table III there appears to be a required level of sebaceous gland development and secretion before Demodex infestation reaches a significant leve1. In the 1-8 year age group incidence is lowest. With the onset of puberty in the 9-17 year age group, Demodex infestation seems to be increasing. In the nert two age groups of adults, the incidence has 
not only. reached a significant level, but the normal and oily skin conditions are clearly much more involved than the dry skin condition. In the oldest age group, although the overall incidence is higher, the dry skin condition shows 22 positive cases and 20 of these are women; a significant difference when compared with the other four age groups. However, one criterion on which determination of the skin condition yras based was questioning of the subject. A considerable number replied that their skin was very dry and in order to retain racial moisture many of the ladies had reduced or elininated soap and water cleansing of the face and relied on cosmetic creams for this purpose. Ayres (1930) described a clinical condition he calls ptyrasis folliculorum which often results from this type of facial hygiene, however it was not detected in any of the subjects in this study. The enly other criterion used to determine skin condition was observation. A quantitative sampling method would have been desireable, but this technique requires complete isolation and protection of the test site and complete immobilization of the subject. The clinical impression of oiliness is not an entixely reliable index of surface lipids according to kligman and Shelley (1958). It is the presence of sweat which imparts the clinical appearance of oiliness. How oily a subject will appear at any one time will be influenced by the chance of his having recently sweated or of having been 
in an environment of high humidity. Oiliness will often appear in a sudden wave-like fashion if on a cool, dry day a subject with moderate to high casual lipid level is suddenly made to sweat. Likewise, emotional sweating will cause a sudden wave-like development of oiliness, If appreciable amounts of oil are present originaliy. Oiliness is less prominent in winter time and especially marked in hot, humid climates. For these reasons, except for frankly seborrheic patients, the correlation between the clinical impression of oiliness anci the actual level of surface lipids is far from perfect. Nevertheless, I still believe the relationship between normal and oily skin, sebaceous gland distribution, development and secretion, and infestation with Demodex folliculorum is not coinci.. dental, but a partial explanation of the parasite's distribution and incidence.

Although Demodex folliculorum lives in and about the sebaceous glands and their fatty secretions, it would seemingly enhance support for the animal's pattern of incidence if sebum served as its food. This is most likely the case, although some workers feel the diet is supplenented with other nutrients. The fine work of S.G. Spickett (1961a) in which Demodex was successfully cultured in vitro in a medium of human sebum leaves little doubt that sebum is the principle, if not exclusive, source of nutrition.

Further support for the increase in incidence of this 
parasite with the advancing age of the host involves the mode of transmission of the mite from person to person. Most workers agree that direct skin to skin contact is the principle means of transference. Spickett's (1961a) work on the life history of Demodex showed that dispersal takes place in the dark, or at least in very dim light. The obvious implication is that human social contact meeting these requirements is more prevalent in adults than in children. But why does the incidence continue to rise in the 51-90 age group? The motherminfant relationship is an intimate one involving much skin contact, yet infestation in infants and young children is negligible or nonexistant. There must be a required level of sebaceous gland developm ment and secretion before mite infestation is enhanced, but the continued increase of incidence into the 51-90 age group requires further study. Cowiry (1939) described a skin condition commonly found after 40 years of age he termed sebaceous hyperplasia in which the sebaceous glands become enlarged and overactive. An abnormal condition such as this however, cannot account for the majority of the population with normal skin conditions which harbor the parasite.

The overall question of hygiene remains ratier obscure as far as infestation with Denodex is concerned. In an attempt to remain random and objective in this survey, subjects were examined for this parasite from al walks of life. 
Although no direct evidence can be sited in this regard, one observation should be noted. Subjects examined in a "skid road" soup kitchen showed no significant deviation in the level of incidence from that of college professors. Without intending to offend either group, it would appear that the only parameters influencing the pattern of incidence are the age of the host which in turn influences the size, development and secretory rate of the sebaceous glands, and social contact with other infested individuals. This can probably be explained by the paritioning of sebun in and on the skin. Free sebum is the excess portion which flows out and over the skin surface from a higher to a lower concentration. It is easily washed away with soap and water and is chiefly responsible for the appearance of oiliness. Further down is the capillary reservoir which contains sebum in the interstices of the stratum corneum network. Repeated washings with soap and water will remove essentially all of this sebum as we11. Finally there is the follicular reservoir which lies beneath the surface and includes all the fully formed sebum in the ducts and follicular infundibulum. The largest reservoits by far are in the sebaceous follicles of the face, and no amount of scrubbing with soap and water will significantly remove this sebum. There is no physiological way to empty the follicular reservoir of sebaceous follicles and mechanical means, such as hemostat pressure, lead to injury of the 
tissue, yet this is the habitat of these mites. For these reasons then, personal hygiene is apparently not a factor in the incidence of infestation of the facial skin with Demodex foliiculorum.

The findings of a number of pathologists gives further support to the theory that the face is definitely the area of optimum occurrence of Demodex fol1iculorum. Nicholas (1943) in a survey of 1750 consecutive samples of unselected tissue submitted for routine histological examination reported the presence of Dernodex in $40(2.28 \%)$. Of the 40,32 were Facial skin samples. Breckenridge (1953) found Demodex in 186 of 1,435 skin sections from various regions of the body and 146 of these were from the face. Finally, Riechers and Kopf (1969) took epidermal sheets from sixteen selected. sites on nine randonly selected cadavers for histological examination. All nine subjects were infested to variable degrees, but the organisus were found only in specimens obtained from the face, neck and chest. It should be noted that all nine subjects were elderly (53 to 91 years of age). Since Demodex is 1 ight sensitive, other areas of the body which receive less 1 ight than the face, would seem more favorable to infestation. Although other areas of the body may be infested, sebaceous gland distribution and activity seem to be more essential to establishment, and the dark confines of the follicles present no 1 ighting problems. Clothing would also be a hindrance so dispersal 
and skin to skin contact, although transfer by towels and clothing should not be ruled out.

A number of workers have mentioned the possibility of seasonal influences on the incidence of Demodex. Baksht (1965) reported an increased incidence in warmer weather and Smith and McCulloch (1969) stated that in cold weather they are not easily isolated whlle in warm weather they are more readily found along the lid margin. Since this study was carried out from November to March, this possibility was not investigated. Spickett's (1961a) experiments have shown that the optimun temperature range for Demodex is $20.370 \mathrm{C}$ and further investigations along this line should be undertaken.

It should be noted that the scalp of man fulfills many of the requirements for Demodex infestation that have been discussed, yet infestation of the scalp remains extremely rare according to the 1 iterature. Miskjian (1951) reported only two such cases in more than ten years of practice as a dermatologist and there are no reports in the literature prior to his paper. Both were bald wen in their fifties ard the mites were found in small papules containing a clear of $1 \mathrm{y}$ liquid. Further study is needed to determine the reasons for the absence of scalp infestations.

Eyelashes. Becker (1876) was the first to find Demodex in the eyelash follicles of man. There are two 
types of sebaceous glands within the eyelids of man; the meibonian glands, which open onto the palpebral margin of the eyelids, and the glands of zeis, with ducts opening into eyelash follicles.

The rows of evenly-spaced meibonian glands at the border of the eyelids are so large that they are easily seen with the naked eye when one inverts the eyelids before a nirror. Although these glands open directly to the surface of the skin and contain vast amounts of sebum like the sebaceous follicles of the face described earlier, there is no evidence that they are more heavily or less heavily infested than the glands of Zeis which empty into the follicles. Coston (1967), in his thesis on Blepharitis, made no attempt to differentiate between the two glands and the presence of mites as they were seen partially emerged fron follicles (Fig. 9). The glands of Zeis were assumed to be involved since the sampling was done by epilating lashes from the lid margins.

The increase in incidence of infestation with the advancing age of the host is most likely due to many of the same factors influencing the chin, cheeks and nasal area of the face: The size and secretory activity of the modified sebaceous glands of the eyelids undoubtedly is part of the answer. Their functioning in lubrication of the specialized cilia provides an ideal habitat for Demodex. Social contact is also a possibility here. The 
influence of personal hygiene is somewhat debateable. In the normal procedure of washing the face very few people actualiy soap the palpebral margins of the lids, in fact the general pattern is just the opposite. Beginning on the cheeks or forehead, the hards usually pass in a cjrcular motion as far as the inner orbit of the eye with the fingers covering both sides and the bridge of the nose. When the soapy hands or washcloth pass over the eyelids, the lids are tightly shut to avoid geting soap in the eyes, thus depriving the lid margins of a thorough cleans. ing. This favors the accumulation of waxy dry debris and collars of mite feces about the base of the cilia and the sebaceous material is not cleaned away, thus providing the mites with a veritable sea of sebum in which to carry on activities.

One final variable in the extremely high incidence in the oldest age group is not intended to offend. In talking with attendants and supervisory personnel at the rest and retirement homes, (from which many of the subjects in the 51-90 groups came) two points should be noted. First, in some, and by no means a11, of the elderly residents there appears to be a general loss of interest in personal hygiene and a thorough cleansing of the eyelids was probably lacking. Secondly, many of the female residents use a great deal of makeup and consequently, cold creams are substituted for soap and water. Although these two points are debateable, 
there could be some question as to the subjects in my $51-90$ year age group being a truly representative sample of the group as a whole.

Squeezing Facial. Follicles. The principle reason for utilizing this method was to demonstrate the technique responsible for early reports on the incidence of infestation. It is interesting to note the same general pattern of incidence with respect to age as has been discussed in this paper was evident in the work of DuBois (1910). Table II shows children under five years were free of mites, half of those from $\hat{x} i v e$ to ten years were infested, and everyone beyond ten years was infested. It is this $100 \%$ incidence from many early workers (Simon, 1842; Wi 1son, 1845; Leydig, 1859; Geber, 1884; Guiart, 1902) that leads to speculation on the trend in demodectic infestation. With this iechnique it is extremely easy to overlook low populations of mites and one must squeeze very hard to exude sebum rather than Propionibacterium. Although my sample size is too small for valid comparison, there is the possibility of a downward trend in incidence due to certain contemporary patterns of living less conducive to Demodex infestation.

Ingrown Hairs. Since many subjects examined in other areas were checked for ingrown hairs on the face or neck it would appear that this is a rather uncommon entity. Of the thirteen males with ingrown hairs on the neck, five 
showed the presence of Demodex within pustule contents. Since the organisms were not found in al1 thirteen subjects exhibiting the pimple-like cysts, the role Demodex may play in their formation is only speculation at best.

According to Breckenridge (1953) the mites which lodge in the hair follicles not only cause dilation of the rollicle, but also may act as a barrier to the normal flow of sebum. The lack of the lubricant may result in fraginentation of the hair shafts and hyperleratosis. Occasional1y a plugged follicle leads to formation of a cyst lined with epidermis and containing the mites as we 11 as the fragmented hair shaft which continues to grow in a curled manner. The projection of the capsule-1ike sheath of keratin surrounding the parasites above the skin surface produce nodules which become apparent to the host. An inflammatory reaction may occur producing slight erythema. Most likely, this explanation is a valid one, but what of the ingrown hairs and nodules which contain no parasites. Dirt and other foreign debris can become a barrier to the normal flow of sebum and the daily razor can provide constant fragmentation of the hair shafts. Cyst formation and inflammation can then follow producing the same results without any mites; or mites found within may not have been the cause of the condition. Whatever the case, the role Demodex may play in the formation of ingrown hairs could be of a facultative nature. 
Chest And Pubic Area. These areas were sampled because reported findings of other workers had indicated the chest and genitals were sometimes infested with Demodex. This does not seem unusual in 1 ight of the criteria for establishment of the mites which has already been discussed. Essentially the presence and high secretory rate of sebaceous glands is often all that is required for infestation. If the glands are large in size and seburn storage capacity, infestation is further enhanced. The areolar glands of the two areola of the chest are modified sebaceous glands and suitable for demodectic infestation. Breckenridge (1953) however, reported finding the mites in the main collecting ducts of the nipple of the breasts and Garven (1946) found them in ten of thirteen nipples after mastectomy. The obvious implication here is the possibility of the parasites being transferred to the nursing infant, however the internal establishment of these mites has never been reported in humans. Modified sebaceous glands on the prepuce, glans penis, and labia minoris produce copious and continuous amounts of smegma. Breckenridge found Demodex in one skin sample of the penis. Although my sample sizes are too small for valid comparison, the incidence in the chest and genital areas throughout the literature indicate these are uncommon sites of demodectic infestation. Since the modified sebaceous glands located in these areas open directly to the surface 
and are primarily hairless, the technique of plucking hairs for examination from the chest and pubic areas was given little chance of success. The chemical and slit 1 amp method was not utilized for obvious reasons and skin sections from cadavers appears to be the best way to demonstrate infestation in these areas.

Ear Wax. The historical significance of this site of infestation was the primary reason for demonstrating the mites in this study. Berger (1842), a Frenchman, was one of the first men to discover Demodex and he found the organisms in ear wax. The modified sebaceous glands located in the external auditory canal secrete a much different type of material than the sebaceous follicles of the face. Most like 1y the sticky, waxy secretion he1ps, along with the hairs withir the ear, to collect debris which might otherwise enter the internal cana1. Daniel, et a1. (1959) reported that Demodex folliculorum lived four months in ear wax in the laboratory. Demodex which I isolated from eyelash follicles were placed in ear wax under controlled conditions in the laboratory, however, they died within a week. Perhaps there are physiological races of Demodex which, once adapted to a particular site on the host for a few generations, are unable to make the transition. Further study is needed in this area. 
be clear from introductory statements that some mites are capable of causing serious dermal and respiratory problems for man through allergic and toxic reactions. Some are also capable of transmitting viral or bacterial disease organisms to man, sometimes with lethal resulis. The status of Demodex folliculorum as a pathogen or vector is on uncertain ground in so far as irrefutable evidence is concerned, because it is a difficult matter to investigate with scientific accuracy. We must examine the habitat and habits of Demodex to determine what opportunities for pathogenicity exist. The anatomical tools and physio1ogical mechanistns possessed by the parasite which would enable it to act as a vector or pathogen rnust also be discussed.

Demodex folliculorum is the on $1 y$ animal consumer found in healthy, undamaged skin. Animals such as itch mites, Sarcoptes scabei, cause obvious damage and proper treatment quickly follows. The remaining cutaneous organisms are yeasts, bacteria, and viruses. Among the residents of the healthy skin are several pathogenic species that live in an uneasy balance with the host. After a long period during which they remain harmless, a change of the internal or external cutaneous environment can upset the equilibrium; then these species multiply and cause problems.

Only a few yeasts are represented in the normal skin flora. Some of them are partially or entirely dependent on 
lipids and grow most abundantly on the scalp and in greasy areas of the face, such as the folds of the nose and the ear. Thus their food and location coincides with that of Demodex, however no other relationships are known. The dominant members of the cutaneous community are Gram-positive bacteria represented by two groups. Almost all of the aerobic cocci are harmless, except in very special circumstances, but one species, Staphylococcus aureus, is the cause of pimples, boils and more serious infections. The chief domicile or this species is the nostrils and the perineurn (the region between the genitalia and the arnus). Both locations are frequented by Demodex, and their possible association cannot be overlooked. The other group is the rod shaped diphtheroids. One species, Corynebacterium acnes, the "acne bacillus," is anaerobic and lives in the depths of the hair follicle where its association with Demodex has been implicated in acne vulgaris, but never proven. It is impossible to say to what extent viruses inhabit the healthy skin, since their presence is difficult to recognize in the absence of damage to the host. Because viruses are parasites on living cells and there are no living cells in the upper layer of skin, any cutaneous virus would have to be living in deeper levels. The transmission of viruses by Demodex would therefore seem to be eliminated, but this may not be so as will be discussed later. On the other hand, the viruses that parasitize 
bacteria (bacteriophages) are present on the skin in significant numbers. The relationship between Demodex and lysogeric bacteria has never been investigated. All of these organisms discussed are normally present on the skin. The great number of other species which are transients, for failing to become established, present other possibilities for associations with Demodex folliculorum and must not be overlooked. It is important that we know the habits of this animal if we are to implicate any of the above associations in a pathogenic situation.

The details of the life cycle of Demodex folliculortun are now known (Spickett, 1961a). The parasite is oviparous, the egg being deposited in the sebaceous gland, the newiy emerged larva feeds on sebaceous material in the sebaceous gland. It is slowly carried to the mouth of the follicle by the flow of sebum, and undergoes two molts, firstly to protonymph and secondly to deutonymph. The deutonymph is the distributive stage, it leaves the follicle and moves over the skin surface. New infestations are started by skin to skin contact and transfer of deutonymphs. The deutonymph enters a new follicle and molts into the adult. The males move over the skin surface entering follicles to feed. Copulation occurs in the mouth of the follicle. The ovigerous female moves further into the follicle and from there into the sebaceous gland. The entire life cycle is about fourteen days; ine period between a mite leaving one 
sebaceous gland as a larva and entering another as an ovigerous female is about eight days. Distribution over the skin surface is accomplished in not more than 36 hours and probably is as short a period as 12 hours. The parasite is not usually found outside the confines of the pilosebaceous apparatus except when on the skin surface during dark or dimly lit hours. It goes in and out of follicles, carrying ion its jegs and body al1 manner of bacteria and fungi that may be present on the skin, but without cellular destruction or tissue damage these organisms cannot gain entry to the body of the host.

Does Demodex provide entry by puncturing cells of the host tissue? Nutting and Rauch (1961) have taken the position, based on anatomical observations of the mites and a study of serial sections of mites in situ, that all members of the genus Demodex at sometime during their life cycle puncture cells and feed upon cell contents. The head or capitulum has been best described anatomically by Hirst (1919) (Fig. 13 and 14). The palpi consist of three distinct segments and each palp can be protruded separately. The second and third segments are freely movable, with the last segment bearing four or five rod-like spines. The chelicerae are needlelike stylets fully capable of puncturing cells, the lower pair being over twice as long as the upper pair, leading Hirst to the conclusion that the food was liquid in form. Other authors (Spickett, 


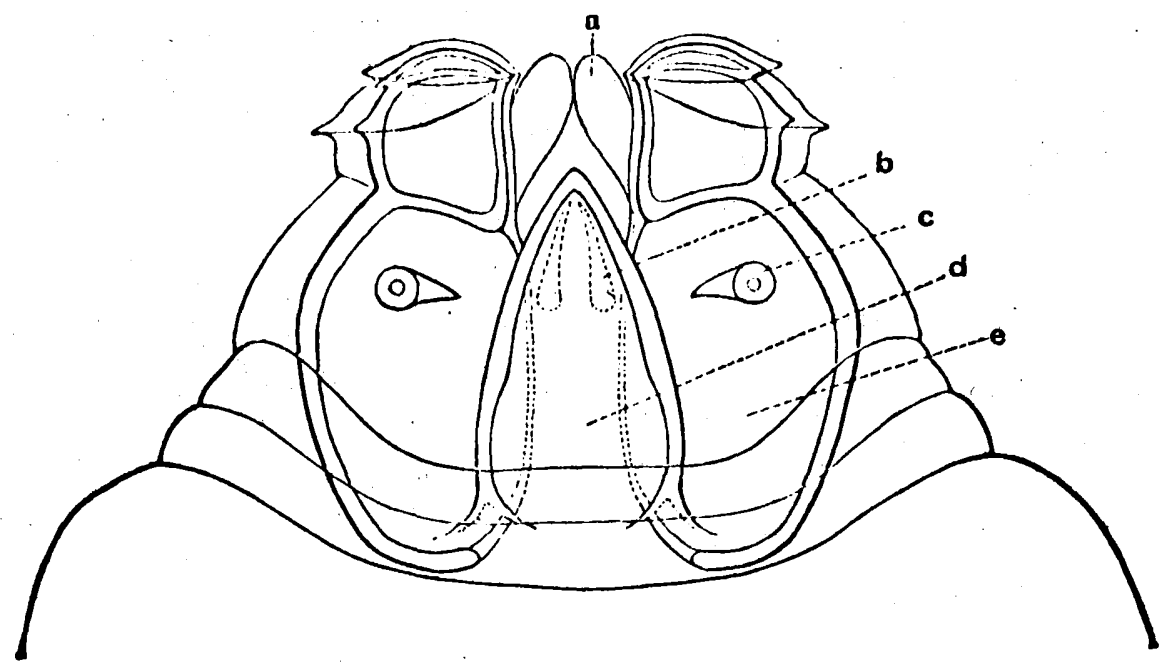

Figure 13. Cnpitulum of Demodex folliculorum, Owen, from above.

a. Labinl sheal bs of chelicerac. b. Chelicera (upper finger).

c. Spine on palp. d. Epistome. e. Palp.

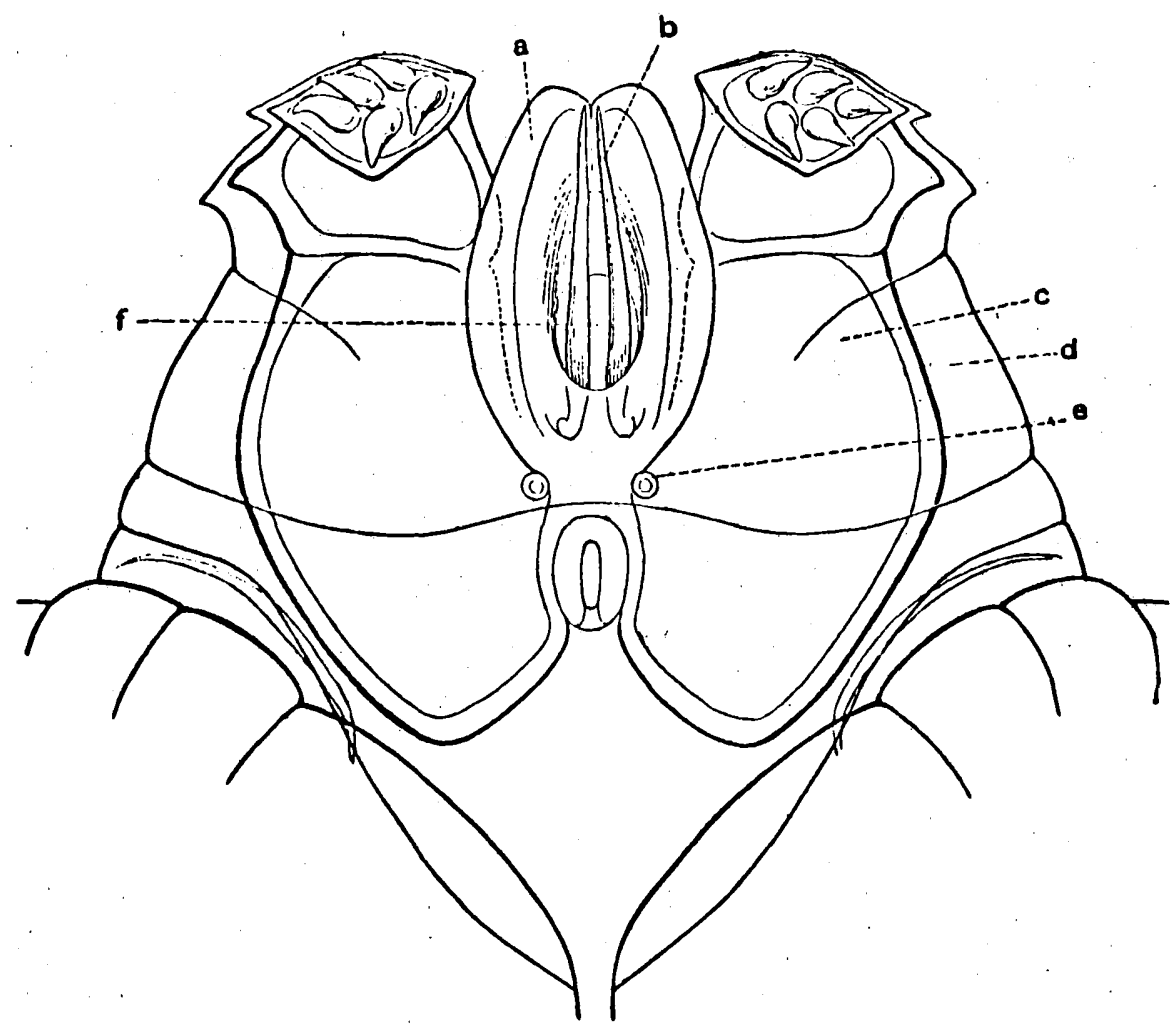

Figure 14. Capitulum of Demodex folliculorum from below.

a. Labial theathe of chelicerw. b. Chelicera (lower finger). c. Palp. d. Membranous capitulum. e. Supposed opening of respirntory syetem. $f$. Mouth. 
1961a; Ayres and Ayres, 1961) still subscribe to the view that sebum alone is sufficient for maintenance and development of the mites. Spickett successfully cultured Demodex in vitro in human sebum. In 1964, Nutting strengthened his position by pointing out that sebum is very low in nitrogen which makes it unlikely as sole food for development of any organism, especially one in which several exoskeletal covers of chitin (a glucosamine) must be secreted. Perhaps there are other sources of nitrogen within the habitat of this anjmal.

Within the sebaceous gland, the mature cells laden with numerous droplets or sebum vesicles, are centrally located near the junction of the sebaceous duct with the hair follicle. During secretion, these cells die when their products are extruded; this process is called holocrine secretion and is brought about through the action of lysosomes (Be11, 1970). The sebum is made up not only of lipid material, but the cellular debris containing nitrogenous compounds. Another source might be the glandular secretions and the byproducts of the process that forms keratin which provides free amino acids as nutrients for the inhabitants of the skin according to Marples (1969). Final1y, the habj tat of Demodex is literally alive with bacteria (Fig. 4) which when taken in with the sebum and cellular debris would provide more nitrogenous nutrients. So if these possibilities are fact, there would appear 
to be no gain for the parasite in the destruction of cells. However, it has been noted that in infestations involving classes of individuals (e.g. children) or sites (e.g. the arm) where parasitism is uncornmon owing to the low level of sebaceous activity, the animals may penetrate the epithelium of the sebaceous giand (Spickett, unpublished). Demodex has mouthparts adapted for piercing and cutting. It has been shown that tre related species Demodex criceti is capable of burrowing into the epidermis of the hamster (Nutting and Ratuch, 1958). Observations on Demodex fol1iculorum suggest that penetration of the sebaceous epithelium can occur, but does so only when there are very many mites in a follicle or where there are mites in follicles in which the associated sebaceous glands are relatively small or inactive as compared with those of the facial skin of adult Oregonians.

Demodex molts three times between leaving one sebaceous gland as a larva and entering another as an adult female. This suggests that it is unlikely that bacteria could be transmitted on the outsids of the param site's body. However, bacilli have been demonstrated on the outside of the body as well as in the gut of Demodex folliculorum (Spickett, 1961b). The bacilli could escape from the alimentary tract of the vector in three ways, either in the feces, in regurgitated material or by the vector being scratched into wounds inflicted by the host 
in response to the irritation it causes.

It has been reported by Ayres (1930) that gross demodicidosis may produce symptoms of itching, but infestations sufficiently heavy to do this are rare. It is unlikely, but not impossible, that transmission of bacteria could be effected through self-inflicted wounds caused by scratching in response to irritation caused by the mites.

The only external opening to the gut of Demodex is the mouth. There is no anus. If the parasite transtits an organism from the subepidermal tissues of one host to those of another it must be through disgorgement of the contents of the alimentary tract. Studies on the feeding mechanism of this mite have shown that there is regurgitation of part of the contents of the alimentary tract; this is probably associated with predigestion of food material. It has been found in an unpublished experiment by spickett that small particles of undigested material (plastic and resin particles were used in lieu of bacteria) may be regurgitated several days after they were first ingested. The shortest time interval between leaving one sebaceous gland and entering another is about five days, in the normal life cycle according to spickett. It is therefore probable that bacteria could be transmitted by these means. Two ovigerous females have been found by spickett (1961b) with acid fast bacilli in their gut. These bacilli could only have come from the sebaceous gland of another follicle 
since at this stage in the life cycle the sebaceous gland of the newly entered follicle has not been reached.

It is, therefore, plausible that any protozoan, fungal, bacterial or viridial agent of a nost which is a contaminant of the skin complex may be transmitted by Demodex folliculorum.

It should be noted that Koch's postulates have not been fulfilled, ard in fact very few diseases have ever been jmplicated in an associatjon with Demodex fol1icuiorum. Table XIII gives ten conditions in which D. foljiculorum bears a suspect causal or cooperative relationship.

\section{TABLE XIII}

CASES IN WHICH DEMODEX FOLLICULORUM BEARS A SUSPECT CAUSAI OR COOPERATIVE REIATIONSHIP

Acne

Blepharitis

Rosacea

Micro-vesicular $\mathrm{rx}$

Pityriasis

Leprosy

Cancer

Hyperkeratinization

Depilation

Inf lammat ory $\mathrm{rx}$
Simon, $184 z$

Coston, 1967 ; Smith and McCul1och, 1969 Ayres and Anderson, 1932

Miskjian, 1951

Ayres, 1930

Borre1, 1909a,b; Spickett, $1961 \mathrm{~b}$

Borre1, $1909 \mathrm{c}$

Ayres and Ayres, 1961

Breckenrioge, 1953

Garven, 1946

Distinct Species? Many workers (Coston, 1967; Smith and McCulloch, 1969) are not completely convinced that the 
Demodex on different animals are really different species: Demodex canis $(\mathrm{dog})$, Demodex bovis (cattle), Demodex cati (cat), Demodex cuniculi (rabit), Demodex phyiloides (swine). This list is not complete by any means. There are a number of criteria available which seem sufficient for distinct species differentiation.

Gross morphology is strikingly different in some species. D. bovis and D. criceti are short and plump animals only half the size of D. folliculorum and D. canis (Figure 1). For finer distinction there is a well-marked tubercle or spine on the largest, most proximal segment of the palp which differs greatly in development in the differ. ent species and affords a good specific character (Hirst, 1919) (Figure 13).

The habitats of many Demodex species differ markedly and help to determine specificity. D. criceti is found singly in epidermal pjts on hamsters, the dimensions of which are rarely larger than the body of the mite. They lie with nouthparts and legs towards the dermis and have never been found in normal hair follicles (Nutting and Rauch, 1958). This, of course, is altogether different from the habitat of D. folliculorum.

Failure of attempts at interspecific host transfer of demodicids by Borre1 (1908) and Nutting (1950) would seem to leave little doubt that distinct species of mites do exist. Although Gruby (1846) and Maynard (1922) reported 
positive transfer between dog and man they both failed to use either marked mites or taxonomic criteria to distinguish the species supposediy transferred from the endemic host to the recipient host.

Final1y, it seems reasonable that transfer from dog to man fails because of specific species requirements, but the failure of man to man transfer in the laboratory is a different matter. Once again, the thought of physiological races of $D$. folliculorum is intriguing and should be studied In the future. It should be recalled from introductory remarks that Sarcoptes scabei often fails to survive a transfer to a new host once adapted for several generations to a given host. So it would appear from the literature to date that there are not only distinct species of Demodex, but possibly more specific races highly attuned to a given habitat on a given host.

Evolutionary Implications. Demodicids are of interest from the point of view of parasite evolution since they (1) show remarkable adaptations to match their unique environment, (2) are seemingly host specific, and (3) are apparently one of the few arthropod ectoparasitic groups which are capable of an endoparasitic existence (Nutting, 1965).

The basic adaptive features of Demodex folliculorum are readily apparent. The vermiform body lacking inarked sensory structures, such as eyes or setae, and short legs 
are well adapted for life in the narrow follicles. However, the overall reduction in size is also apparent when the follicle mites are compared to their surface dwelling counterparts. The stylet-like mouthparts and sac-1ike alimentary tract are adaptations favoring food sources liquid in nature which are entirely absorbed. It is interesting that two separate species of denodicids, Demodex aurati afd Demodex criceti, both found on the Golden Hamster are markedly different in body configurations (Nutting, 1961). D. aurati is elongate which conforms to its habitat in the hair follicle whereas $D$. criceti is squat. The latter is found in simple pits which it apparentIy excavates in the epidermis. Larval and nymphal stages of $D$. Caprae (goat) and $D$. bovis which inhabit papules or nodules are remarkable either for their reduced appendages or greatly modified opisthomae. Nutting feels that as new demodicids are discovered such adaptive features will form a conerent evolutionary pattern.

Even though host specificity is far from assured in the Demodicidae the fact that (1). they are so weakly mobile, (2) no internediate host is apparently involved in transferrence (Nutting, 1950) and (3) interspecific transfer, if it ever occurs in nature, is certainly difficult would indicate marked species stability.

Nutting (1964) has added some additiona1 information to the original. work of Hirst (1919) regarding evolutionary 
affinities of Demodex folliculorum. There appears to be a pattern of evolution leading from orjginally commensalpredator types to mites which wandered freely over the buccal mucosa of a variety of animals. Increasing specialization can be traced from our present knowledge of the niche requirements of certain species. D. criceti in epidernal pits, D. folliculorum and D. aurati in hair follicles, D. bovis and D. caprae in nodules and rinally D. canis in the blood system show the increasing intimacy of the host-parasite relationship with a corresponding increase in pathogenicity. Nutting suggests a symbiotic relationship between bacteria (Staphylococcus pyogenes a1bus) and $D$. canis as the latest step in the progress of the Demodicidae from ectoparasitism to endoparasitism. 


\section{REFERENCES CITED}

Ayres, S. Jr. 1930. Pityriasis folliculorum (Demodex). Arch. Dermat. and Syph., Chicago, 21 (I): 19-24.

Ayres, S. Jr. and N. Anderson 1932. "Demodex folliculorum: Its role in the etiology of Acre Rosacea. Arch. Dermat. and Syph., Chicago, 25: 89.101.

Ayres, $S .3 r$, and S. Ayres III 1961. Demodectlo eruptions (Detnodicidiosis) in the human. Arch. Dernat., 83: $816-827$.

Baker, E.W., and G.W. Wharton 1952. Ar Introduction to Acarology. Macmillan Co., New York.

Baksht, B.P. 1965. Role of the mite Demodex folliculorum hominis in human stin pathology. Vestn. Derm. Vener., 7: 31 :

Becker, Grafem Saemisch 1876. Handbuch der gesanten Augenhbeilirunde, vo1. 4: $375-436$.

Beerman, H. and J. Stokes, 1934. Rosacea complex and Demode. folliculorun. Arch. Dernat. and Syph , Chicago, 2.9 $874-884$.

Be11, Mary 1970. Sebaceous Glands. Primate News, vol. E, no. 2, Feb.

Berger, F. 1845. Compt. rend. hebd. Acad. sci. (Paris), 20: 1506 .

Borre1, A. 1908. Demodex et infections cutanees. Comp. Rend. Soc. Biol., Paris, 65: 596-597.

Borre1, A. 1909a. Lepre et Demodex. Compt. Rend.Acad. Sci., Paris, $148(I): 50-51$.

Borre1, A. 1909b. Acariens et lepre. Ann. Inst. Pasteus, Paris, 23: 125-128.

Borre1, A. 1909c. Acariens et cancers (avec la collaboraw tjon de Gastine 1 et Gorescu). Bul1. Ass. Fran. Etude Carcer, 2(I): 29-53. 
Breckenridge, R. 1953. Infestations of the skin with Demodex folliculorum. Am. J.C1in. Path. 23 (4): $348-352$.

Coston, T.O. 1967. Demodex folliculorum Blepharitis. Trans. Emer. Ophtha1. Soc., 65: 361-392.

Cowdry, E.V. 1939. Problems of Ageing. The Williams and Wilkins Co. Baltimore.

Danie1, M*, V. Bozdech and C. Moucka 1959. Vyskyt trudnika tukoveho (Demodex folliculorum Owen 1843) v lidia jeho epjdemiologie. Ceskosiov. Epidemiol. Microbiol.,

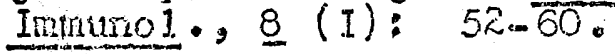

DuBois, 1910 Recherche du Demodex fol1iculorum hominis dans 1 a peau saine, Ann. Dermat. et Syph., 1: 188.

Emanue1,15. 1936. Quantitative Determinations of the Sebaceous Glands: Function, with Particular Mention of the Method Employed. Acta Dermat. Venereo1., 17: $444 \ldots 456$.

Essig, E.O. 1958. Insects and Mites of Western North America. Macmillan Co., Nev York, p. 43.

Friedman, R. 1942. Biology of Acarus scabiei. Froben Press, New York.

Garven, H.S.D. 1946. Demodex folliculorum in human nipple, Lancet, 2: $44-45$.

Gmeiner, F. 1908. Demodex folliculorum des Menschen und der Tiere, Arch. Dermato1. Syphi101., 92: 25-96.

Gruby, D. 1846. Observations on the animalcules which occupy the sebaceous follicles of man, and on the disease of the skin occasioned by their inoculation in the dog. Monthly Jour. Med. SC. (71) I (5): $333-336$.

Hirst, S. 1919. Studies on Acari I. The genus Denodex,

Johnson, C.G., and K. Mellanby 1942. The parasitology of human scabies. Parasitology, 34: 285-290.

Kenda11, M.G. and A. Stuart 1966. Advanced Theory of Statistics Vol. III, Hafner Publish. Co., New York.

Kirk, E. 1948. Quantitative Determinations of the Skin Lipid Secretion in Middle-aged and old Individuals. J. of Gerontology, 3(4): 251-266. 
K1igman, A.M. and W.B. Shelley 1958. An investigation of the biology of the human sebaceous gland. J. Invest. Dermato1. 30: 99-125.

Leydig, S. 1859. Arch. Naturges., 25: 338.

Marples, Mary 1969. Life on the Human Skin. Sci. Amer., 220 (1): $108-115$.

Maynard, W. 1922. A case of follicular mange transmitted from dog to man. Vet. J. (569) 78 (II): 435.

Miskjian, H. 1951. Demodicidois is (Demodex Infestation of the Scalp). (Abstract) Arch. Dermat. and Syph., Chicago, 63(2): 282-283.

Montagna, W. 1962. The Structure and Function of Skin. Academic Press, New York and London.

Nicholas W. 1943. Demodex folliculorum. Its incidence in routine histologic study or the skin. Arch. Dermat. and Syph., Chicago, $47(6)$ : 793-796.

Nutting, W. 1950. Studies on the genus Demodex Owen (Acarina, Demodicoidae, Demodicidae). Ph.D. Thesis, Corne 11.

Nutting, W. and H. Rauch 1958. Detodex Criceti n. sp. (Acarina: Demodicidae) with notes on its biology. J. Parasitology, 44 (3): 328-333.

Nutting, $W$. and $H$. Rauch 1961. The effect of biotin deficiency in Mesocricetus auratus on parasites of the genus Demodex. J. Parasitology, 47: 319-322.

Nutting, H. 1961. Demodex aurati sp. nov and D. Criceti, ectoparasites of the Golden Hams ter (Mesocricetus auratus). Parasitology, 51: 515-522.

Nutting, W. 1964. Demodicidae -- Status and Prognostics. Acarologia, 6: $441-454$.

Nutting, W. 1965. Host-Parasite Relations: Demodicidae. Acarologia, 7: $301-318$.

Riechers, R. and A. Kopf 1969. Cutaneous Infestation With Dernodex Fol1iculorum In Man. J. Invest. Dermato1., 52: $103-106$. 
Simon, G. 1842. Uber eine in den kranken und normalen Haarsacken des Menschen lebende Milbe. Arch. Anat.s Physio1. u Wissensch. Med., pp. 218-237.

Smith, S. and C. MCCulloch 1969 . Demodex folliculorum Palpebrarum. Canad. J. Ophtha1. 4:3-15.

Spickett, S. 1961a. Studies on Demodex folliculorum Simon (1842) I. Life His tory. Parasitology, 51: $181-192$.

Spickett, s. 1961b. A preliminary note on Demodex folliculorum simon (1842) as possible vector of Ieprosy. Leprosy Rev., 32 (4): 263-268.

Wilson, 1844 . Researches into the structure and develop. ment of a newly discovered parasitic animalcule of the hutian skin, the Entozoon folidculorum, Philos, Tr. Roy. Soc. (Londons s. 305 . 
ADDITIONAL REFERENCES

Baker, E.W., T.M. Evans, D.J. Gould, W.B. Hull and H.L. Keegan 1956. A Manual of Parasitic Mites Of Medical Or Economic Importance. National Pest Control Assoc. Inco, New York.

Butcher, E.O. and J.P. Parne11 1948. The Distribution and Factors Influencing the Amount of Sebuin on the Skin of the Forehead, J. Invest. Dermato 1. 10: 31-38.

Carruthers, C. 1962. Biochemistry of Skin in Health and Disease, Charles C. Thomas, Springfields IIJinois.

Chandier. A.C. and C.P. Read 1961. Introduction to Parasi.. tology. John Wiley \& Sons, Inc., NeW York-LondonSyaney.

Cheng, T.C. 1964. The Biology of Anjmal Parasites. W.B. Saunders Co., Philadelphia \& London.

Crouch, J.E. 1965. Functional Human Anatomy. Iea \& Febiger, Philadelphia.

Ellis, R.A. 1958. Ageing of the Humarn Scalp. In "The Biology of Hair Growth" (W. Montagna and R.A. Ellis, eds.) pp. 469-485. Academic Press, New York.

Fuss, F. 1933. Parasitjc 1ife of Demodex folliculorum hominis. Ann. de Dermat. et Syph., 4: 1053-1062.

Harrison, R.J. and W. Montagna 1969. MAN. Meredith Corp., New York.

Hirst, S. 1919b. On the Origin and Affinities of the Acari of the Family Demodicidae. London (British Museum Natural History).

Iverson, K., A. Videbaek and J.E. Kirk 1953. Casual skin iipid levels in individuals of various ages. J. Geronto 1. 8: 312 .

Li, J.C.R. 1964. Statistical Inference. Edwards Bros., Ann Arbor, Mich. 
Mackenna, R.M.B., V.R. Wheatley and A. Wornal1 1950. The composition of the surface skin fat (sebum) from the human forearm. J. Invest. Dermat. 15: 33.

Post, $C$. and $E$. Juhlin 1963. Demodex folliculorum and Blepharitis. Arch. Dermat. 88: $298-302$.

Way, S.C. 1931. The Sebaceous Glands. Their Histopathology and Role in Diseases of the Skin. Arch. Dermat. \& Syph., 24: 353-370.

Wharton, G.W. 1970. Mites and Commercial Extracts of House Dust. Science, 167: 1382-1383. (Mar.). 